\title{
The Critical Role of Basement Membrane-Independent Laminin $\gamma 1$ Chain during Axon Regeneration in the CNS
}

\author{
Barbara Grimpe, ${ }^{1}$ Sucai Dong, ${ }^{3}$ Catherine Doller, ${ }^{1}$ Katherine Temple, ${ }^{2}$ Alfred T. Malouf, ${ }^{2}$ and Jerry Silver ${ }^{1}$ \\ Departments of ${ }^{1}$ Neurosciences and ${ }^{2}$ Pediatrics, School of Medicine, Case Western Reserve University, Cleveland, Ohio \\ 44106, and ${ }^{3}$ Department of Neurobiology, University of Pittsburgh, Pittsburgh, Pennsylvania 15261
}

\begin{abstract}
We have addressed the question of whether a family of axon growth-promoting molecules known as the laminins may play a role during axon regeneration in the CNS. A narrow sickleshaped region containing a basal lamina-independent form of laminin exists in and around the cell bodies and proximal portion of the apical dendrites of CA3 pyramidal neurons of the postnatal hippocampus. To understand the possible function of laminin in axon regeneration within this pathway, we have manipulated laminin synthesis at the mRNA level in a slice culture model of the lesioned mossy system. In this model early postnatal mossy fibers severed near the hilus can regenerate across the lesion and elongate rapidly within strata lucidum and pyramidale. In slice cultures of the postnatal day 4 hippocampus, $2 \mathrm{~d}$ before lesion and then continuing for 1-5 $\mathrm{d}$ after lesion, translation of the $\gamma 1$ chain product of laminin was reduced by
\end{abstract}

using antisense oligodeoxyribonucleotides and DNA enzymes. In the setting of the lesioned organotypic hippocampal slice, astroglial repair of the lesion and overall glial patterning were unperturbed by the antisense or DNA enzyme treatments. However, unlike controls, in the treated, lesioned slices the vast majority of regenerating mossy fibers could not cross the lesion site; those that did were very much shorter than usual, and they took a meandering course. In a recovery experiment in which the DNA enzyme or antisense oligos were washed away, laminin immunoreactivity returned and mossy fiber regeneration resumed. These results demonstrate the critical role of laminin(s) in an axon regeneration model of the CNS.

Key words: extracellular matrix; hippocampus; organotypic slice cultures; reactive astrocytes; glial scar; dendritic spines; axon guidance; antisense ODN; DNA enzyme
The environment surrounding CNS lesions is composed of a complex mixture of both axon growth-promoting and inhibitory cell surface molecules (Eddleston and Mucke, 1993; Fouad et al., 2001; Tang et al., 2001) as well as extracellular matrix (ECM) proteins (Rudge and Silver, 1990; Pindzola et al., 1993; Stichel and Muller, 1994; McKeon et al., 1995; Canning et al., 1996; Giger et al., 1998; Fitch et al., 1999; Niederost et al., 1999; Pasterkamp et al., 1999; Asher et al., 2000; Lemons et al., 2001) for which the functional interactions with the cut end of the axon are dependent on the particular region that is damaged, the maturational state of a given axon tract, as well as the proximity of the reactive cells to the heart of the lesion. Although robust axon regeneration through or around lesions usually fails after CNS injury, there are interesting exceptions (Kalil and Reh, 1979; Kunkel-Bagden et al., 1992; Dow et al., 1994; Chauvet et al., 1995; Doucette, 1995; Davies et al., 1997, 1999; Fry and Saunders, 2000; Magavi et al., 2000; Scharff et al., 2000; Fischer et al., 2001). What might be the molecular mechanisms that underlie the dramatic axon growth-promoting potential of certain forms of the regeneration-permissive reactive tract phenotype that develop, on occasion, in the CNS? The laminins are a 15 member family of

Received Sept. 24, 2001; revised Jan. 9, 2002; accepted Jan. 28, 2002.

This work was supported by the Daniel Heumann Fund for Spinal Cord Research, National Institute of Neurological Disorders and Stroke Grants NS25713 (to J.S.) and NS41383 (to A.T.M.), The Brumagin Memorial Fund, and the International Spinal Research Trust. We thank Dr. U. Mayer for continuous support and helpful comments; Drs. E. Deneris, J. C. Probst, and W. J. Brunken for critically reading this manuscript; Dr. W. Halfter for his strong support with the in situ hybridization experiments; and Albert Ries for exceptional technical help.

Correspondence should be addressed to Dr. Jerry Silver, Department of Neurosciences, School of Medicine, Case Western Reserve University, 10900 Euclid Avenue, Cleveland, OH 44106. E-mail: jxs10@po.cwru.edu.

Copyright (C) 2002 Society for Neuroscience $0270-6474 / 02 / 223144-17 \$ 15.00 / 0$ large cruciform glycoproteins (Timpl et al., 1979; Burgeson et al., 1994; Koch et al., 1999) that, in the nervous system, are produced mainly by Schwann cells (Cornbrooks et al., 1983), olfactoryensheathing glia (Obremski and Bunge, 1995; Ramon-Cueto and Avila, 1998; Li et al., 1999), astroglia (Liesi and Silver, 1988; Liesi and Risteli, 1989; Liesi, 1990), and neurons (Zhou, 1990; Jucker et al., 1991; Hagg et al., 1997). The potent axon growth and guidance capacities of the various laminin subtypes have been demonstrated repeatedly in tissue culture assays (Edgar et al., 1984; Gundersen, 1987; Smith et al., 1990; Liesi et al., 1992; Calof et al., 1994; Kennedy and Tessier-Lavigne, 1995; Kuhn et al., 1995; Matsuzawa et al., 1996; Ivins et al., 1998; Powell et al., 2000). In vivo, although there is a great deal of evidence in support of the critical role of laminin in PNS regeneration (Zhou, 1990; Jucker et al., 1991; Patton et al., 1997; Ferguson and Muir, 2000) (see also Bonner and O'Connor, 2001), relatively little is known about the possible role of the laminins in the process of axon regeneration in the mammalian CNS that can occur within the context of a nonscarred, intratract glial framework.

One model for investigating the influence of laminin during successful regeneration of the cut axon in the brain is the mossy fiber pathway in the hippocampus. Mossy fibers originate from granule cells in the dentate gyrus and synapse in the hilus and in the stratum lucidum of the CA3 area, stopping abruptly at the CA3-CA2 border (Gaarskjaer, 1986). Importantly, the mossy fiber pathway shows a remarkable degree of plasticity throughout life (Steward, 1976; Amaral and Dent, 1981; Laurberg and Zimmer, 1981; McWilliams and Lynch, 1983; Eriksson et al., 1998) and is capable of complete regeneration of its normal synaptic pattern when transected in organotypic slice cultures (Zimmer and Gähwiler, 1987; Nguyen et al., 1996). Furthermore, the path- 
way over which the axons regenerate is decorated richly with a form of intraparenchymal laminin that is one of the few in the CNS that is clearly and easily demonstrable with immunohistochemistry (Zhou, 1990; Hagg et al., 1997; Nakagami et al., 2000). Characterization of a regeneration-stimulating role for particular ECM molecules is important if we are to understand how the CNS may be able to repair itself intrinsically or be induced to repair itself after devastating injuries.

To investigate the possible role of laminin in this particular case of CNS axon regeneration, we found the specific reduction of one protein or one family of proteins in postnatal animals to be of high interest. Gene-targeting experiments for different laminin chains such as LAMC1, which codes for the laminin $\gamma 1$ chain, result in the death of the embryo (Smyth et al., 1999). Although these observations highlight the absolute biological prerequisite for functional laminin interactions during development, the demise of the laminin-deficient embryo limits the possibility for further investigations of laminin function.

The antisense-targeting technology in combination with DNA enzymes allows for the large-scale downregulation or even complete inhibition of particular proteins in vivo or in situ. In our experiments, synthetic oligodeoxyribonucleotides (ODNs) were used for specific hybridization with an expressed target, the laminin $\gamma 1$ chain mRNA. Antisense ODNs or DNA enzymes physically bind to the target gene transcript, producing a nucleic acid duplex and, in the latter case, actually cut the target mRNA specifically, which leads to the inhibition of translation (Probst and Skutella, 1996; Grimpe et al., 1999). For the present experiments we have used these techniques to interrupt the formation of nearly all known forms of laminin during regeneration of the mossy fibers in an organotypic hippocampal slice culture model. With the use of this strategy we demonstrate experimentally, for the first time, the critical role of laminin(s) in regeneration of an axon tract in the mammalian CNS.

\section{MATERIALS AND METHODS}

Hippocampal slice cultures and immunohistochemistry. Hippocampal slice cultures were prepared from 4-d-old Sprague Dawley rat pups by the method of Stoppini et al. (1991). Rats were decapitated, and $400 \mu \mathrm{m}$ transverse hippocampal slices were prepared with a Siskiyou Designs brain slicer (Grants Pass, OR). Slices were placed on $25 \mathrm{~mm}$ Nunc Anopore tissue culture inserts (Naperville, IL) in six-well tissue culture plates and fed every $3 \mathrm{~d}$ with $1.5 \mathrm{ml}$ of growth medium [50\% MEM, 25\% HBSS (Invitrogen, San Diego, CA), and 25\% horse serum]. For staining the mossy fibers, $0.1-0.5 \mu \mathrm{l}$ of Micro Ruby $3 \mathrm{kDa}$ (Molecular Probes, Eugene, OR) coupled to dextran was injected with the use of a Marzhauser micromanipulator into the granule cell layer by following the general procedure described by Harrigan et al. (1995). The cultures were incubated for $1.5 \mathrm{hr}$ in an incubator at $5 \% \mathrm{CO}_{2}$ and $37^{\circ} \mathrm{C}$, followed by fixation in $4 \%$ paraformaldehyde (PFA) in $0.1 \mathrm{M} \mathrm{PB}(1.9 \mathrm{~mm}$ $\mathrm{NaH}_{2} \mathrm{PO}_{4} \times \mathrm{H}_{2} \mathrm{O}$ and $\left.8 \mathrm{~mm} \mathrm{Na}_{2} \mathrm{HPO}_{4} \times 7 \mathrm{H}_{2} \mathrm{O}\right)$ for 3-4 hr. The slice cultures were washed two times in $10 \%$ sucrose, once in $30 \%$ sucrose, and then incubated in $30 \%$ sucrose overnight. To enhance antibody penetration, we then freeze-thawed the cultures three times in $30 \%$ sucrose on dry ice, washed them two times in $10 \%$ sucrose, once in $0.1 \mathrm{M}$ TB ( $80 \mathrm{~mm}$ Trizma-HCl, $20 \mathrm{~mm}$ Trizma Base), and once in $0.1 \mathrm{M}$ TBS [containing (in mM) 80 Trizma-HCl, 20 Trizma Base, $150 \mathrm{NaCl}, 2 \mathrm{KCl}$ ] for $15 \mathrm{~min}$. After the cultures were blocked for $1 \mathrm{hr}$ with blocking solution (3\% goat serum, 3\% BSA, $1 \%$ Triton X-100, $1 \%$ DMSO in 0.05 M TBS), the slices were washed again in TBS for $1 \mathrm{hr}$ with a change of the solution every 5 min (Kunkel et al., 1994). Then the slice cultures were incubated with the first antibody against mouse glial fibrillary acidic protein (GFAP; 1:500, Sigma, St. Louis, MO) for 2 or $3 \mathrm{~d}$. This was followed by rinsing in TBS for $1 \mathrm{hr}$ and then by overnight incubation with the second antibody (anti-mouse) coupled with Oregon green or Alexa 488 (1:500, Sigma; 1:500, Molecular Probes). This second antibody was preincubated with rat serum (Sigma) for $30 \mathrm{~min}$ at room temperature before use. Finally, the cultures were washed in TBS for $2 \mathrm{hr}$ and mounted with ImmunoFluor Mounting Medium (ICN Biochemicals, Aurora, $\mathrm{OH}$ ). The double immunofluorescence labeling was analyzed by confocal laser-scanning microscopy with a Zeiss (Oberkochen, Germany) microscope in an inverted configuration. The $z$-section rotation was done with Zeiss software.

Laminin staining of hippocampal sections and slice cultures. Hippocampal sections $(400 \mu \mathrm{m})$ of postnatal day 4 (P4) as well as adult (6 month to 1 year) Sprague Dawley rats or living P4 slices $(400 \mu \mathrm{m})$ cultured for 1-7 $\mathrm{d}$ were used unfixed, fresh-frozen, or fixed with $2 \%$ PFA and $0.05 \%$ glutaraldehyde for $\sim 1 \mathrm{hr}$, followed by rinsing in $1 \times$ PBS [containing (in mM) $1 \mathrm{KH}_{2} \mathrm{PO}_{4}, 10 \mathrm{NaHPO}_{4}$, and $2.7 \mathrm{KCl}$, plus $0.137 \mathrm{M} \mathrm{NaCl}, \mathrm{pH}$ 7.4]. The unfixed fresh-frozen $\mathrm{P} 4$ hippocampi were sectioned with a cryostat (Bright Instrument, UK; Hacker Instruments, Fairfield, NJ), followed by the staining procedure described below. The fixed cultured slices were removed gently from the insert with a brush and washed for 3-4 hr or overnight with $1 \times$ PBS on an orbital shaker. Then the slice cultures or sections were blocked with $10 \%$ normal goat serum in $1 \times$ PBS for at least $1 \mathrm{hr}$ at room temperature on a shaker. The primary antibody against human laminin $\gamma 1$ chain made in mouse, clone 2E8 (1:100, Invitrogen), Engelbreth-Holm-Swarm (EHS) laminin made in rabbit (1:25, Sigma), neurocan made in rabbit [NC 2; 1:2000, a generous gift by Uwe Rauch (Oleszewski et al., 1999)], or rabbit serum as a negative control (in a dilution of the respective antibodies, 1:100 and 1:2000) as well as only the second antibody, which never showed any staining, was left on the sections or slices for $2 \mathrm{~d}$ at $4^{\circ} \mathrm{C}$ on an orbital shaker. After $2-3 \mathrm{hr}$ of rinsing in $1 \times$ PBS ( $\sim 6-8$ changes), the tissues were put in secondary antibody coupled with Alexa 594 (1:200, goat against mouse or rabbit $\mathrm{IgG}$; Molecular Probes) overnight at $4^{\circ} \mathrm{C}$ on a shaker. The next day the tissues were again rinsed for several hours and then mounted with Citifluor mounting medium (Ted Pella, Redding, CA). The 2E8 antibody has been characterized by Engvall et al. (1986), and electron microscopic (EM) rotary shadow images showed the binding domain of this $\gamma 1$ antibody to be in the P1 fragment of the laminin molecule.

Antisense and DNA enzyme design and treatment. Antisense oligonucleotides and DNA enzymes were designed as end-capped phosphorothioate ODNs of three or two bases on each end. They were obtained from a commercial supplier (MWG Biotech, Ebersberg, Germany). The sequence corresponded to the $3^{\prime}$ end of the published laminin $\gamma 1$ chain mRNA sequence (accession number X94551; Vanden Heuvel et al., 1996). It is well away from the coding sequence of all netrins (Manitt et al., 2001) and had no homology to other mammalian sequences registered in the GenBank databases of National Institutes of Health (Altschul et al., 1997).

Hippocampal slice cultures were pretreated for $2 \mathrm{~d}$ with the specific concentration $(0.05,0.1,0.5,2$, and $8 \mu \mathrm{M})$ of antisense [Lamy1as2, 5'-ATG GTC CGG TTG ATG GCG GG-3', nucleotides position in the sequence 401-420 (Vanden Heuvel et al., 1996)] or mixed base (Lamy1mb2, 5'-GCG CCC ATC AAC CGG AGT CA-3') ODNs every day or, in the untreated control slices, with nothing. The respective DNA enzyme targeted the same sequence of the laminin $\gamma 1$ chain mRNA. However, for the catalytic digestion of the targeted mRNA the DNA enzyme contained a loop structure (Santoro and Joyce, 1997) and had the following sequence of DNA enzyme: 5'-GGT CCG GTG GCT AGC TAC AAC GAG ATG GCG G-3', nucleotides position in the sequence 402-418 (Vanden Heuvel et al., 1996). The control DNA mixed base enzyme lacked the ability to digest target mRNA and the inability to bind to any other sequence [control DNA enzyme (mixed base), 5'-TCG ACG GTA GCA ACA TCG ATC GGG ATG TGA C-3']. Lesions were made in the hilar portion of the CA3 region of slice cultures with a surgical blade (stainless steel, size 15, Feather, Fisher Scientific, Pittsburgh, PA). The cultures were treated every day for 1 or $5 \mathrm{~d}$ further with $2 \mu \mathrm{l}$ of the specific concentration of antisense, DNA enzyme, or mixed base ODNs or were allowed to develop untreated. The slice cultures either were subjected to immunocytochemistry or were used for RNA isolation.

Quantification. To characterize the density of mossy fibers that cross lesion sites in contrast to the density of fibers that do not, we lesioned slice cultures after $2 \mathrm{~d}$ of pretreatment. The slices were treated further with antisense or mixed base ODNs for $5 \mathrm{~d}$ more, and the mossy fibers were stained as described above. Photomicrographs were taken with a Nikon Optiphot-2 fluorescence microscope connected to a SPOT color charge-coupled device camera (Diagnostic Instruments, Sterling Heights, MI).

For the semiquantitative analysis of axon regeneration, an area on both sides of the lesion and a background region were defined, and the 

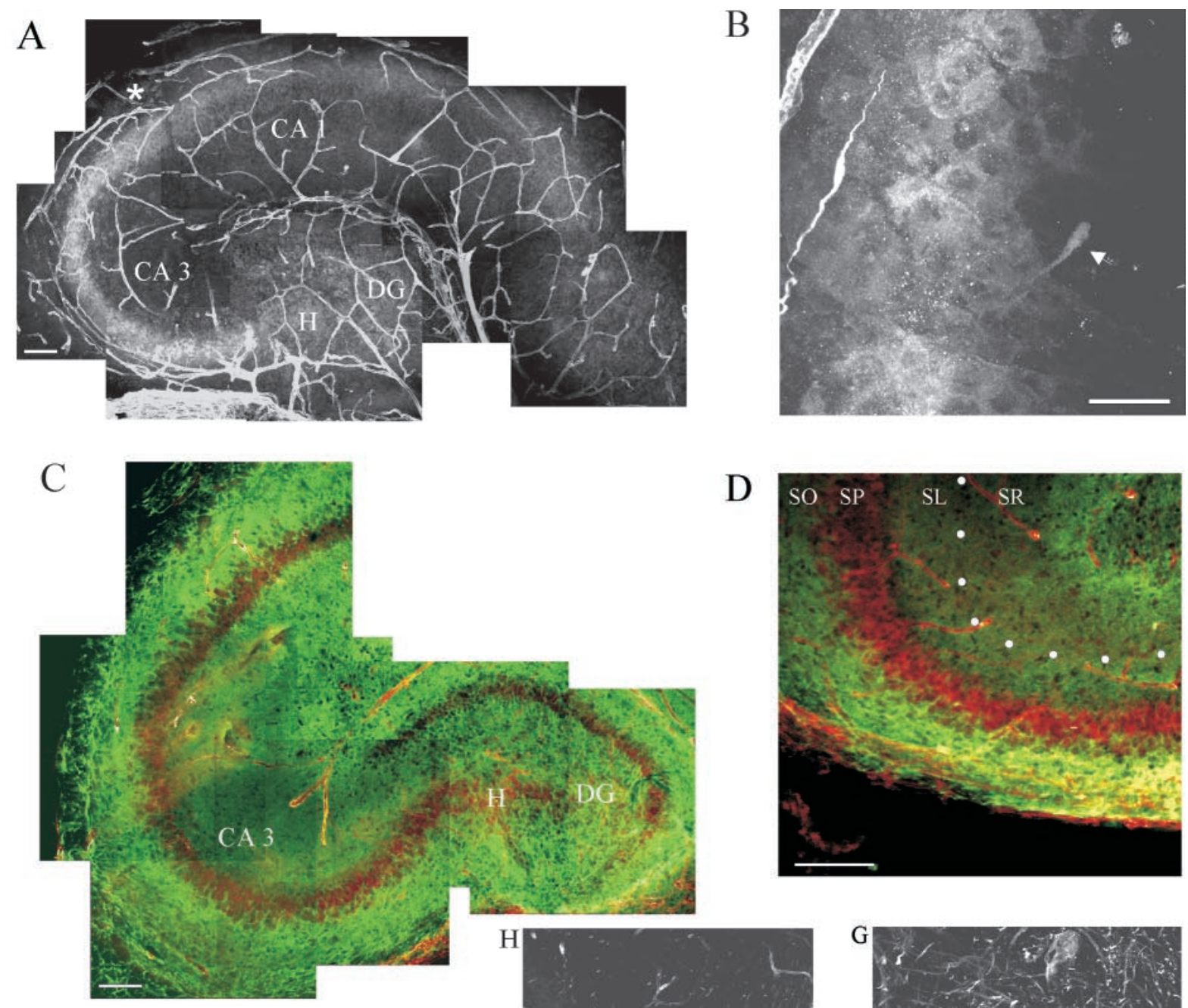

D
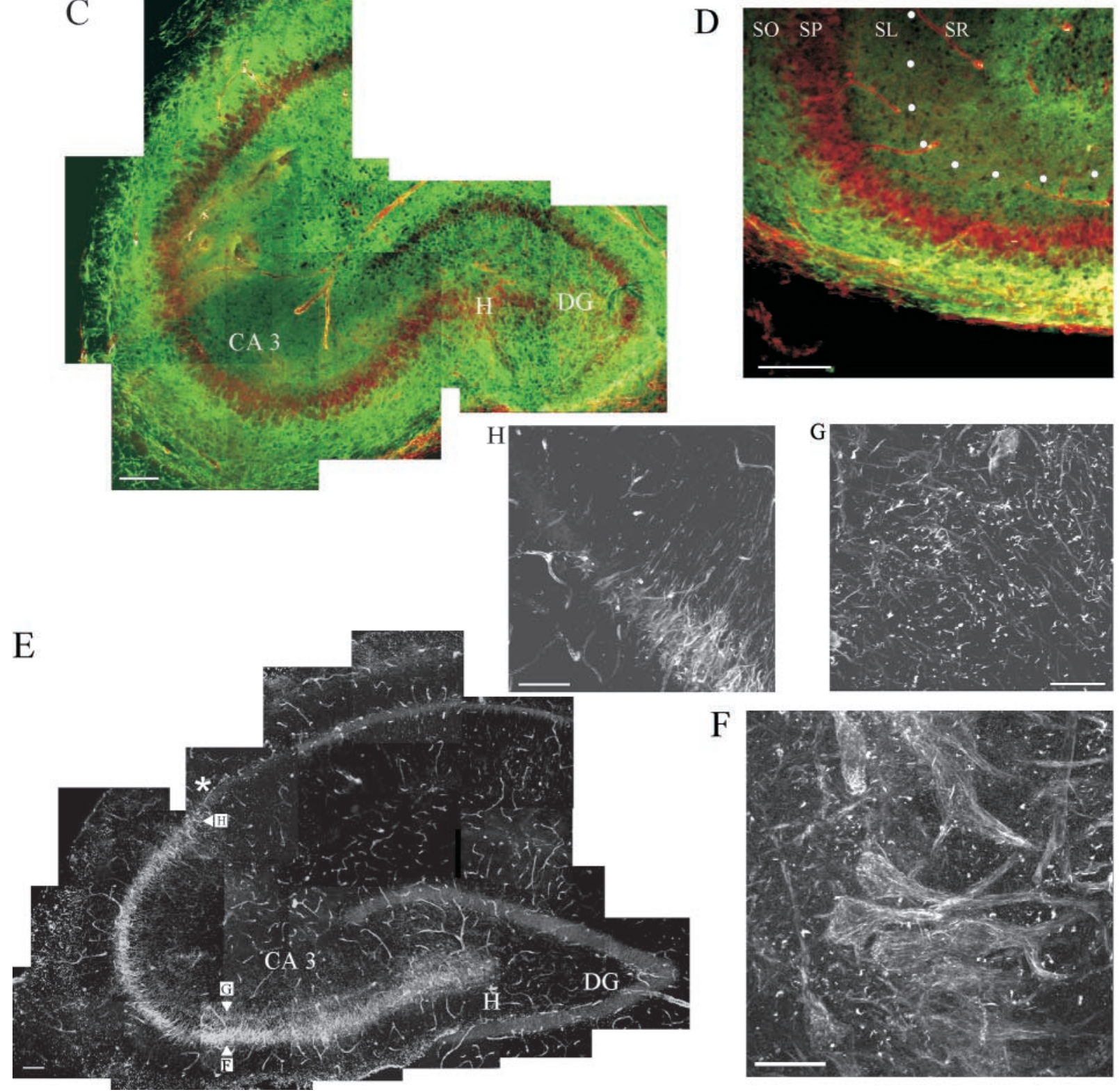

Figure 1. Shown are freshly fixed P4 $(A-D)$ and adult $(E-H)$ hippocampal sections (20- $\mu$ m-thick) stained for the $\gamma 1$ chain of laminin and for neurocan and imaged with a confocal laser microscope. $A$, Pathway of punctate laminin staining in the stratum pyramidale and stratum lucidum, starting in the hilar region $(H)$ of the dentate gyrus $(D G)$ and ending at the CA3-CA2 border (asterisk). The blood vessels of the hippocampus are stained also. Scale bar, $100 \mu \mathrm{m}$. $B$, Higher magnification of this pathway, which shows the cell bodies and proximal portion of the apical dendrites of the pyramidal neurons stained for laminin $\gamma 1$ (arrowhead). Scale bar, $25 \mu \mathrm{m}$. C, A P4 hippocampal section is stained for neurocan ( green) and laminin (Figure legend continues.) 
intensities were measured with TINA 2.09 (Raytest GmbH, Straubenhardt, Germany). In the profile window the baseline was subtracted from the intensity measurement. For the statistical evaluation (percentage, average, SD) Excel (Microsoft, Redmond, WA) was used. The percentages of regeneration at three specific distances one point proximal (point A) and two points distal to the lesion (points B and C) were calculated for each slice culture. A schematic diagram, which explains where the measurement points were taken, is presented in Figure 6. For the average amount of regeneration at each distance, the individual percentage rates from each slice culture from each concentration group of antisense or mixed base ODN were totaled and divided by the numbers of slices in their group. These results are shown in Table 1 also.

Immunoprecipitation. Twelve hippocampal slices in culture for $7 \mathrm{~d}$ were treated with 0.05 or $8 \mu \mathrm{M}$ DNA enzyme and control DNA enzyme (mixed base). The slices were collected in immunoprecipitation buffer [containing (in mM) 10 Tris-HCl, pH 7.6, $150 \mathrm{NaCl}, 0.2$ PMSF, 1 EDTA, $\mathrm{pH}$ 8, plus $1 \%$ Triton $\mathrm{X}-100,0.5 \% \mathrm{NP}-40]$ and kept at $-80^{\circ} \mathrm{C}$ until they were used. Then they were triturated, and the protein concentration was measured with the BCA assay (Pierce, Rockford, IL) on a spectrophotometer at a wavelength of $590 \mathrm{~nm}$. Identical amounts of protein from DNA enzyme-treated and control DNA enzyme-treated (mixed base) slices were extracted with $500 \mu \mathrm{l}$ of $0.5 \mathrm{M} \mathrm{NaCl}$ and $0.05 \mathrm{M}$ Tris, $\mathrm{pH}$ 7.7, solution. After centrifugation the supernatant was dialyzed against $1 \times$ PBS overnight. On the next day the proteins were biotinylated with 200 $\mu l$ of EZ-linked sulfo- $N$-hydroxysuccinimide-biotin (Pierce) for 30 min at room temperature on a shaker. The solution was cleared with a $3 \mathrm{hr}$ incubation with an actin IgG2a antibody and protein A-Sepharose at $4^{\circ} \mathrm{C}$ on a shaker, followed by a short centrifugation. The supernatant was incubated for $1 \mathrm{hr}$ with the $\gamma 1$ chain laminin antibody (clone $2 \mathrm{E} 8 ; 2 \mu \mathrm{l}$ of mouse ascites, Invitrogen) at $4^{\circ} \mathrm{C}$ on a shaker. The solution was incubated with protein A-Sepharose overnight at $4^{\circ} \mathrm{C}$ on a shaker. The next day each solution was washed two times, with a $20 \mathrm{sec}$ centrifugation in between, with the three following solutions: wash buffer $1(150 \mathrm{mM} \mathrm{NaCl}$, $50 \mathrm{~mm}$ Tris- $\mathrm{HCl}, \mathrm{pH} 7.4,1 \% \mathrm{NP}-40)$, wash buffer $2(500 \mathrm{~mm} \mathrm{NaCl}, 50$ mM Tris-HCl, $\mathrm{pH} 7.4,0.1 \%$ NP-40), and wash buffer 3 (50 mм Tris-HCl, $\mathrm{pH} 7.4,0.1 \%$ NP-40). After removal of the third wash buffer the precipitates were incubated for $5 \mathrm{~min}$ at $95^{\circ} \mathrm{C}$ in Laemmli buffer $(0.1 \mathrm{M}$ dithiothreitol; Laemmli, 1970) under reducing conditions. The probes were separated electrophoretically in a $4-12 \%$ SDS-PAGE (Bio-Rad, Hercules, CA) in $1 \times$ TGS running buffer $(3.03 \mathrm{gm}$ of Tris Base, $14.4 \mathrm{gm}$ of glycine, $1 \mathrm{gm}$ of SDS for $1 \mathrm{l}$ ), starting with $60 \mathrm{~V}$ and increasing to 100 $\mathrm{V}$. The gel was blotted electrophoretically on a nitrocellulose membrane (Bio-Rad) in $10 \mathrm{~mm}$ sodium borate (borax) buffer overnight at $4^{\circ} \mathrm{C}$. On the next day the membrane was blocked with $3 \%$ BSA in TBS $(10 \mathrm{~mm}$ Tris, $\mathrm{pH} 8,150 \mathrm{~mm} \mathrm{NaCl}$ ) for $2 \mathrm{hr}$ at room temperature, followed by a 2 $\mathrm{hr}$ incubation of $250 \mathrm{~mm}$ streptavidin-coupled horseradish peroxidase in $1 \%$ BSA in TBS-T (10 mm Tris, $\mathrm{pH} 8,150 \mathrm{~mm} \mathrm{NaCl}, 0.1 \%$ Tween 20 ) for $2 \mathrm{hr}$ further on a shaker. To remove unbound streptavidin-horseradish peroxidase, we rinsed the membrane in TBS-T ( $\sim 6-8$ changes), followed by developing with the ECL kit (Amersham Biosciences, Arlington Heights, IL).

Western blot analysis. Ten microliters of the supernatant from the immunoprecipitated $0.05 \mu \mathrm{M}$ treated DNA enzyme and control DNA enzyme [DNA mixed base (mb)] protein extract were mixed with $10 \mu \mathrm{l}$ of Laemmli buffer (Laemmli, 1970) and incubated for 5 min at $95^{\circ} \mathrm{C}$. The solution was loaded on a $4-12 \%$ SDS-PAGE (Bio-Rad) in $1 \times$ TGS running buffer, starting with $60 \mathrm{~V}$ and increasing to $100 \mathrm{~V}$. The gel either was stained with Coomassie blue R-250 in $9.5 \%$ acidic acid and $43 \%$ methanol, followed by a destaining solution of $10 \%$ acidic acid and $10 \%$ methanol, or was blotted electrophoretically on a nitrocellulose membrane (Bio-Rad) in $10 \mathrm{~mm}$ sodium borate (borax) buffer overnight at $4^{\circ} \mathrm{C}$. On the next day the membrane was blocked with $5 \%$ low fat milk powder in TBS-T buffer for at least $2 \mathrm{hr}$ at room temperature. Then the mem- brane was incubated with a mouse monoclonal antibody against GFAP (1:500, Chemicon, Temecula, CA), $\beta$-actin (1:500, Sigma), in $5 \%$ low fat milk powder in TBS-T overnight on a shaker at $4^{\circ} \mathrm{C}$. On the next day the membrane was washed with TBS-T for $5 \mathrm{hr}$ (several changes) and incubated with the second goat antibody (which recognizes mouse IgG labeled with horseradish peroxidase; 1:500, Chemicon) in 5\% low fat milk powder in TBS-T overnight at $4^{\circ} \mathrm{C}$. To remove unbound secondary antibody, we rinsed the membrane for $5 \mathrm{hr}$ in TBS-T (several changes), followed by incubation of the membrane with the ECL kit (Amersham Biosciences).

In situ hybridization. The probe for nonradioactive in situ hybridization against the $\gamma 1$ chain mRNA was a gift from Yoshihiko Yamada (Sasaki and Yamada, 1987). It contains the mouse V and VI domains of the $\gamma 1$ chain mRNA of laminin (position 333-1668) cloned in pBluescript II SK (Stratagene, La Jolla, CA). After a Qiagen plasmid preparation (Chatsworth, CA) in accordance with the manufacturer's protocol, the plasmid was linearized by a NotI digestion for the antisense probe and with $\mathrm{XhoI}$ for the sense control probe. To purify the reaction product, we used a purification kit from Stratagene. This was followed by the labeling reaction with dioxigenin (DIG; Boehringer Mannheim, Indianapolis, IN) for $2 \mathrm{hr}$ at $37^{\circ} \mathrm{C}$ to a cRNA probe by using $\mathrm{T} 7$ polymerase. The RNA was precipitated by using Pellet Paint (Novagen, Madison, WI), 0.1 volume of $3 \mathrm{M}$ sodium acetate, $\mathrm{pH}$ 5.2, and 2 volumes of cold $100 \%$ ethanol. For quality control the probe was separated electrophoretically on an agarose gel.

Freshly prepared P4 mouse hippocampi (C57BL/6J) were fixed for 12 $\mathrm{hr}$ in $4 \% \mathrm{PFA} / \mathrm{PBS}$, followed by incubation in $30 \%$ sucrose in $1 \times$ PBS overnight. On the next day $25 \mu \mathrm{m}$ coronal sections were cut on a cryostat (Bright Instrument, UK; Hacker Instruments), transferred to cold Superfrost plus slides (Fisher brand), and stored at $-80^{\circ} \mathrm{C}$. All solutions were made with DEPC-treated (diethyl pyrocarbonate) water, followed by autoclaving. The sections were air dried for $1 \mathrm{hr}$ at room temperature and post-fixed in 4\% PFA/PBS for $10 \mathrm{~min}$ at room temperature. After being rinsed in PBS three times, the sections were digested with proteinase $\mathrm{K}(1 \mu \mathrm{g} / \mathrm{ml}$ in $50 \mathrm{~mm}$ Tris, $\mathrm{pH} 7.5$, and $5 \mathrm{~mm}$ EDTA) for $7 \mathrm{~min}$, followed by a further fixing step in $4 \%$ PFA/PBS for $5 \mathrm{~min}$ at room temperature and then three more rinses in PBS for $3 \mathrm{~min}$. The acetylation reaction was performed by mixing $3.3 \mathrm{ml}$ of triethanolamine with $0.513 \mathrm{ml}$ of a $10 \% \mathrm{HCl}$ in $246 \mathrm{ml}$ of DEPC-treated water. Then $0.75 \mathrm{ml}$ of acetic anhydrite was added and mixed by dipping the slides carefully several times, followed by a $10 \mathrm{~min}$ incubation at room temperature. The slides were covered with prehybridization solution $(50 \%$ formamide, $5 \times$ SSC, $5 \times$ Denhardt's reagent, $250 \mu \mathrm{g} / \mathrm{ml}$ baker's yeast RNA, and 500 $\mu \mathrm{g} / \mathrm{ml}$ salmon sperm) and incubated for $2 \mathrm{hr}$ at room temperature in a humidified chamber. This prehybridization solution was poured off and replaced by the same solution, which now contained the DIG-labeled 1.3 $\mathrm{kb}$ laminin $\gamma 1$ probe $(200-400 \mathrm{ng} / \mathrm{ml})$. The slides were heated for $5 \mathrm{~min}$ to $80^{\circ} \mathrm{C}$. The sections were coverslipped with HybriSlip (Grace Bio-Labs) and placed in a humidified chamber in which Kimwipes were soaked in a solution containing $5 \times \mathrm{SSC}$ and $50 \%$ formamide overnight at $72^{\circ} \mathrm{C}$. The next day the coverslips were removed by placing the sections in $72^{\circ} \mathrm{C}, 5 \times$ $\mathrm{SSC}$ for $5 \mathrm{~min}$. The slides were washed further in $0.2 \times$ SSC warmed to $72^{\circ} \mathrm{C}$ for $1.5 \mathrm{hr}$. The sections were rinsed in $0.2 \times \mathrm{SSC}$ for $5 \mathrm{~min}$ at room temperature and incubated in buffer $\mathrm{B} 1(0.1 \mathrm{M}$ Tris, $\mathrm{pH} 7.5,0.15 \mathrm{M} \mathrm{NaCl})$ for $5 \mathrm{~min}$ further at room temperature, followed by an $1 \mathrm{hr}$ incubation at room temperature with $10 \%$ heat-inactivated goat serum in buffer B1. The sections were incubated in a humidified chamber at $4^{\circ} \mathrm{C}$ overnight in buffer B2 (1:5000; anti-DIG antibody in 1\% heat-inactivated goat serum in buffer B1). The next day the hippocampal sections were rinsed three times in B1 buffer for $5 \mathrm{~min}$ on a shaker and equilibrated with B3 for $5 \mathrm{~min}$, followed by an incubation with the developing buffer B4 $(100 \mathrm{mg} / \mathrm{ml}$ nitroblue tetrazolium, $50 \mathrm{mg} / \mathrm{ml}$ 5-bromo-4-chloro-3-indolyl phosphate, $0.24 \mathrm{mg}$ of levamisole) for $1.5 \mathrm{~d}$ at room temperature in the dark. The reaction was

(Figure legend continued.) $\gamma 1$ chain (red). Note that the staining for laminin is situated between layers of neurocan staining. Scale bar, $100 \mu \mathrm{m} . D$, Higher magnification of the CA3 region of another hippocampal section showing the reduced staining of neurocan in the stratum lucidum ( $S L$; marked by white dots) and stratum pyramidale $(S P)$ and the increased staining for neurocan in the stratum oriens $(S O)$. Scale bar, $100 \mu \mathrm{m}(S R$, stratum radiatum). $E$, Histological cross section through the hippocampus of a 1-year-old animal stained for the $\gamma 1$ chain of laminin. Note that the pattern and extent of the pathway resemble that at $\mathrm{P} 4$. The cell bodies and apical dendrites of the pyramidal neurons in CA 3 contain a filamentous network containing the $\gamma 1$ chain of laminin. Additionally, a globular form of laminin is present in the cell body region but especially in the striatum lucidum. Scale bar, $100 \mu \mathrm{m}$. The positions from which $F, G$, and $H$ were taken are shown in $E$. F, Higher magnification of laminin staining in the pyramidal cell bodies and proximal apical dendrites. Scale bar, $25 \mu \mathrm{m}$. $G$, Inner part of the stratum lucidum with its obvious globular form of the $\gamma 1$ chain of laminin. Scale bar, $25 \mu \mathrm{m}$. The asterisk in $E$ marks the end of the laminin pathway that appears to be at the CA3-CA2 border. A higher magnification of this border is shown in $H$. Scale bar, $25 \mu \mathrm{m}$. 

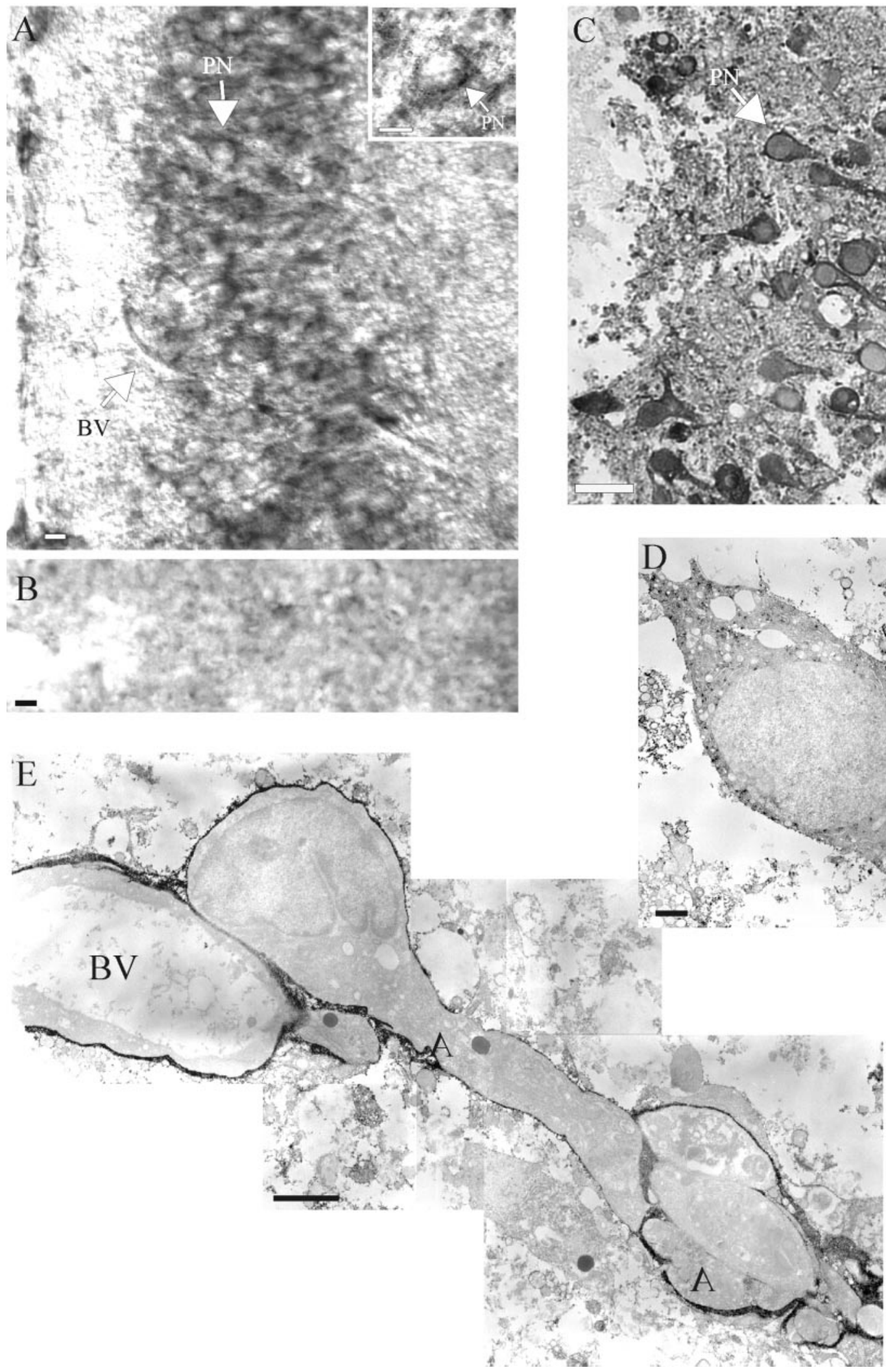
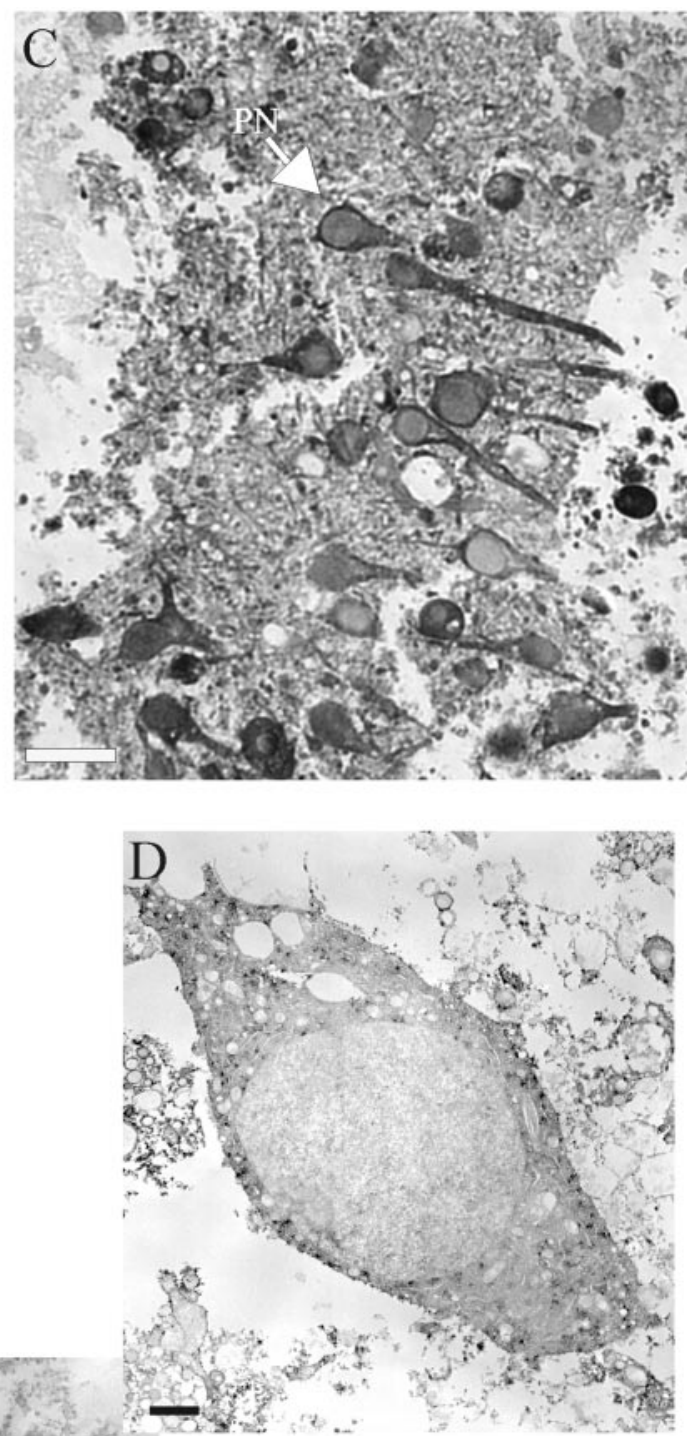

Figure 2. A, In situ hybridization against the $\gamma 1$ chain of laminin in the CA3 region of a P4 mouse hippocampus. The cell bodies of pyramidal neurons $(P N)$ are stained $(B V$, blood vessel). The inset demonstrates a higher magnification confocal image of a labeled neuron $(P N)$. Scale bars, $10 \mu \mathrm{m} . B, \mathrm{CA} 1$ region of the same section that lacks $\gamma 1$ chain mRNA. Scale bar, $10 \mu \mathrm{m}$. $C$, Semithin section $(1 \mu \mathrm{m})$ of a P4 untreated/uncut rat hippocampal slice that had been in culture for $24 \mathrm{hr}$ and stained for the laminin $\gamma 1$ chain. The cell bodies of pyramidal neurons (arrow) and their apical dendrites express laminin. Scale bar, $25 \mu \mathrm{m} . D$, E, EM immunohistochemical staining of the $\gamma 1$ laminin chain (no heavy metal counterstain was used) in ultrathin sections taken from the same slice from which the $1 \mu \mathrm{m}$ section was taken ( $B V$, blood vessel; $A$, astrocytes). Note in $D$ the intracellular laminin reactivity within the cytoplasm of a pyramidal neuron cell body. Note also the intense extracellular staining associated with astrocyte membranes $(E)$. Scale bar, $1 \mu \mathrm{m}$. 


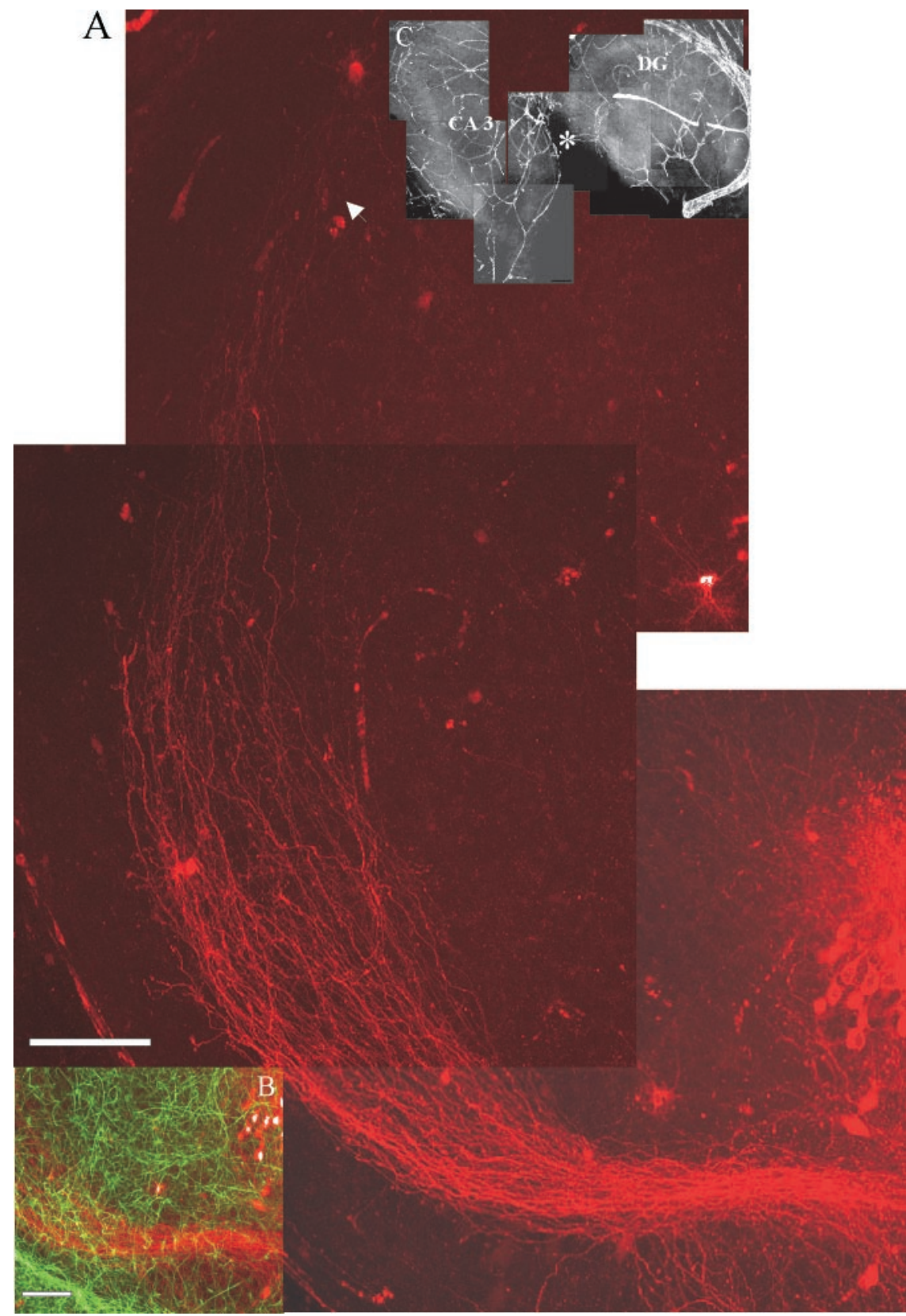

Figure 3. Confocal images of control hippocampal slices. $A$, The sickle-shaped pathway of mossy fibers stained with Micro Ruby in untreated/uncut rat P4 hippocampal slice cultures after $7 \mathrm{~d}$ in vitro. The arrowhead marks the distalmost axons. Note that the path of the mossy fibers resembles the shape of the laminin pathway shown in Figures $1 A$ and $4 A$. B, The pattern of the astrocyte network stained with GFAP antibodies (green), which does not predict the position of the mossy fibers. $C$, An untreated slice culture, which shows the typical position of the lesion immediately after surgery at the beginning of the CA3 region (the lesion is marked by an asterisk). The slice was in culture for $3 \mathrm{~d}$, lesioned, fixed, and stained for the $\gamma 1$ chain of laminin. The widening of the lesion is attributable to a histological processing artifact ( $D G$, dentate gyrus). Scale bars, $100 \mu \mathrm{m}$. stopped by rinsing the sections in $\mathrm{H}_{2} \mathrm{O}$ and mounting them with glycerol. The sections were viewed with a Leitz Orthoplan microscope (Wetzlar, Germany) under differential interference contrast optics and digitally photographed with an Optronics digital camera (Chelmsford, MA).

$R N A$ isolation and PCR. After $7 \mathrm{~d}$ of treatment of three slice cultures each per concentration with antisense and mixed base ODNs ( 0.05 and 8 $\mu \mathrm{M})$, the slices were lysed and homogenized in Trizol (Invitrogen). The same procedure was performed on four slices after $3 \mathrm{~d}$ of treatment with $8 \mu \mathrm{M}$ DNA enzyme and control DNA enzyme (mixed base). Total RNA was prepared according to the supplier's protocol, adding yeast tRNA (Invitrogen) at a concentration of $10 \mu \mathrm{g} / \mu \mathrm{l}$ as a carrier to help precipitation. From each sample $2 \mu \mathrm{g}$ (for the antisense group) or $3 \mu \mathrm{g}$ (for the DNA enzyme group) of total RNA was reverse transcribed into cDNA by using the GenAmp RNA PCR Core Kit (PerkinElmer Life Sciences and Roche, Emoryville and Palo Alto, CA) in accordance with the manufacturers' instructions. The step cycle program for the PCR was set to denaturation at $94^{\circ} \mathrm{C}$ for $30 \mathrm{sec}$, annealing at $59^{\circ} \mathrm{C}$ for $45 \mathrm{sec}$, and extension at $74^{\circ} \mathrm{C}$ for $40 \mathrm{sec}$ for 35 cycles. The primers were obtained from a commercial supplier (MWG Biotech) and had the following sequences: laminin $\gamma 1$-specific primers rLamy1as10, $5^{\prime}$-CAT TCT TCT GCA CGC CACTG-3' and rLamy1s10, 5'-GT GAC AAA GCC GTG
GAG ATC-3' (Vanden Heuvel et al., 1996). The step cycle program for the nested PCR was set to denaturation at $94^{\circ} \mathrm{C}$ for $30 \mathrm{sec}$, annealing at $65^{\circ} \mathrm{C}$ for $45 \mathrm{sec}$, and extension at $74^{\circ} \mathrm{C}$ for $40 \mathrm{sec}$ for 30 cycles [laminin $\gamma 1$-specific nested primers: rLamy1as11, 5'-CCT CTC CGC CTC GTG GGC TT-3' and rLamy1s11, 5' -CCC CTG TGG ACT CGG AGG CT-3' (Vanden Heuvel et al., 1996)]. This resulted in a product of $450 \mathrm{bp}$ in length. $\beta$-Actin $\left[\beta\right.$-actin-specific primers, acts $5^{\prime}$-ATC GTG GGC CGC CCT AGG CAC- $3^{\prime}$ and acts $5^{\prime}$-TGG CCT TAG GGT TCA GAG GGG C-3' (Nudel et al., 1983)] were amplified as a control to test RNA integrity and to estimate the amount of RNA that was subjected to each PCR. The actin amplification was performed as described previously (Grimpe et al., 1999). The reaction products had a length of $240 \mathrm{bp}$. A PCR for the laminin $\beta 2$ chain was used for the DNA enzyme group as a control to show the specific digestion of the laminin $\gamma 1$ chain and the normal expression of other laminin chains. The conditions for the laminin $\beta 2$ chain PCR were the following: denaturing at $94^{\circ} \mathrm{C}$ for $30 \mathrm{sec}$, annealing at $67^{\circ} \mathrm{C}$ for $45 \mathrm{sec}$, and elongation at $74^{\circ} \mathrm{C}$ for $40 \mathrm{sec}$. The reaction formed a product of $349 \mathrm{bp}$. The sequences of the PCR primers were $\operatorname{rLam} \beta 2 \mathrm{~s}, 5^{\prime}$-TCC AGA CCC CTA CAG CTC ACG G-3' and rLam $\beta 2$ as, $5^{\prime}$-GCC CGT TGC ACT CAC ACT TCC G-3' (Hunter et al., 1989). All RT-PCRs were analyzed on $1.5 \%$ agarose gels, stained with 


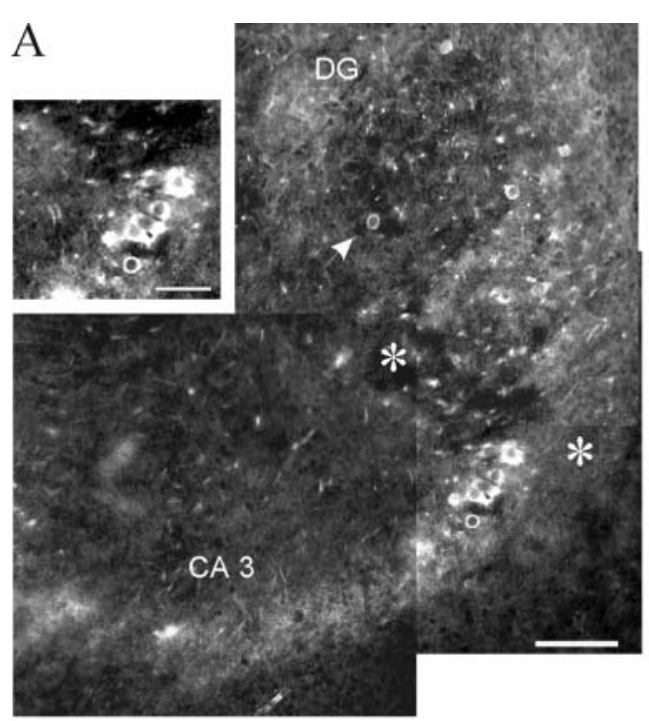

C

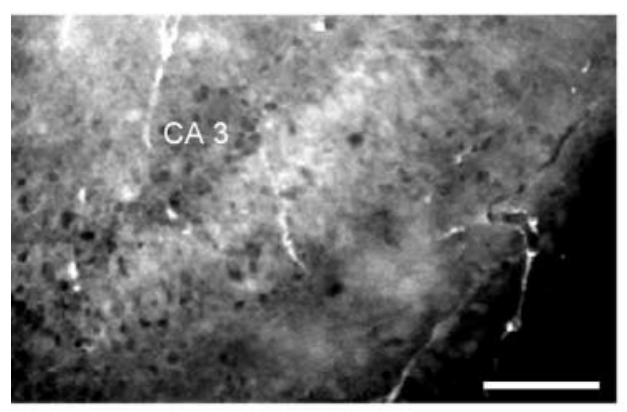

E

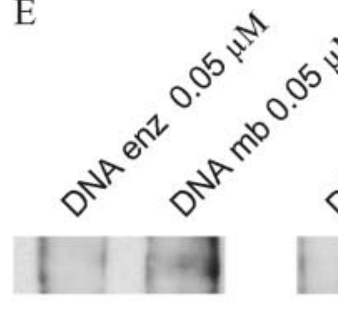

Laminin gamma 1 chain
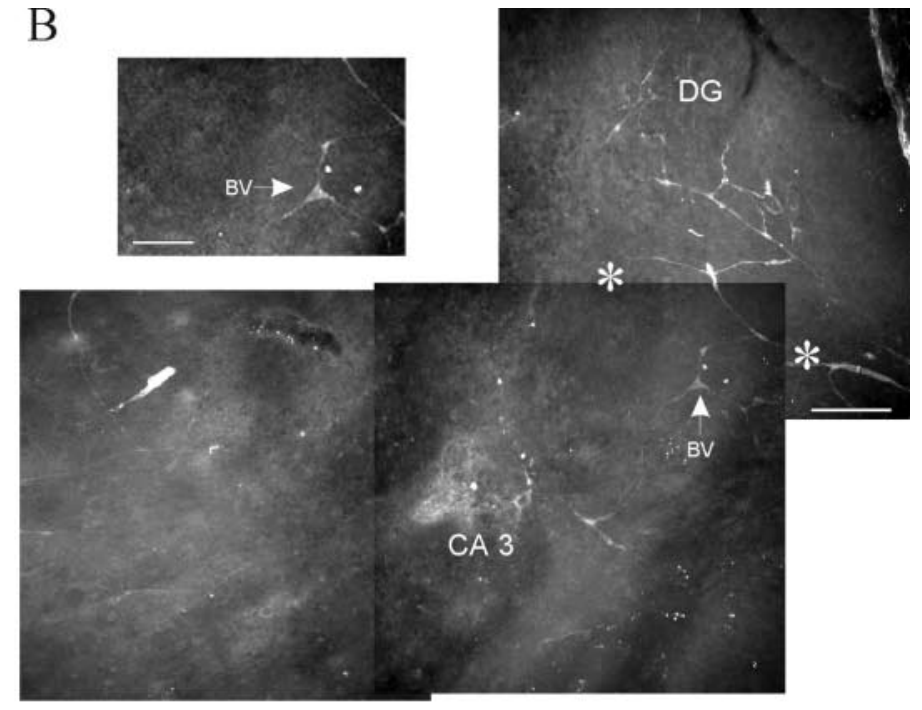

D

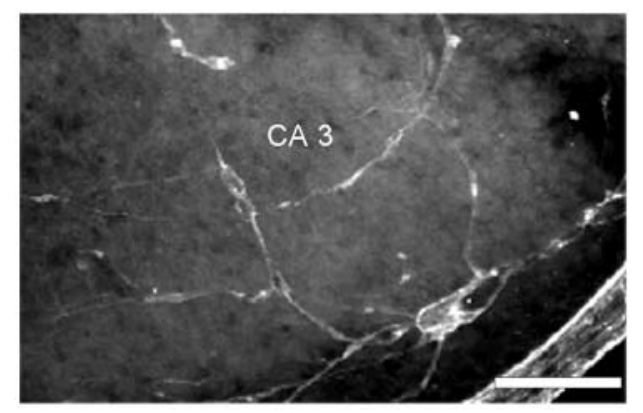

F

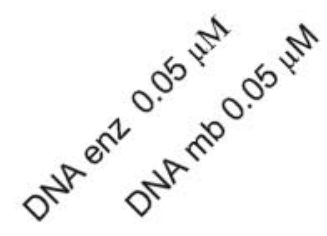

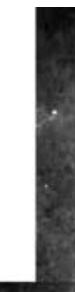

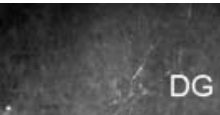

DG

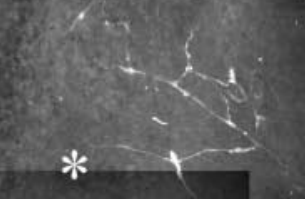

.

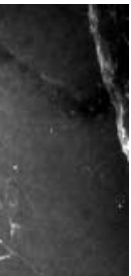


ethidium bromide, and photographed with a Polaroid camera (Kodak, Rochester, NY).

Southern blot analysis. The oligodeoxynucleotide risLamy1as1 [5'CAG CAA GAG CCT TGG CAG CGT CGG CTC GAG CTA GGA GTT GGT CAG CGG TCT GCT G-3' (Vanden Heuvel et al., 1996) obtained from a commercial supplier (MWG Biotech)] specific for the laminin $\gamma 1$ chain was DIG labeled according to the manufacturer's protocol (Boehringer Mannheim). The amplified cDNA after antisense ODN or DNA enzyme treatment was separated electrophoretically on a $1.5 \%$ agarose gel. The gel was denatured for $15 \mathrm{~min}$ in $3 \mathrm{M} \mathrm{NaCl}$ and 0.4 $\mathrm{M} \mathrm{NaOH}$, followed by a $15 \mathrm{~min}$ incubation in transfer solution $(3 \mathrm{M} \mathrm{NaCl}$ and $8 \mathrm{~mm} \mathrm{NaOH}$ ), and blotted onto Hybond $\mathrm{N}^{+}$(Amersham Biosciences) as described previously (Sambrook et al., 1989). The next day the membrane was blocked and treated according to Engler-Blum et al. (1993). CDP-star (PerkinElmer Life Sciences and Roche) was used as a detection reagent. The blots were exposed to Amersham Hyperfilm for 1 and 2 sec.

\section{RESULTS}

\section{In situ hybridization and immunohistochemical staining for laminin mRNA and protein in P4 and adult hippocampus and the relationship of mossy fibers to the laminin pathway in hippocampal slices}

The laminin $\gamma 1$ chain is part of 10 of the 15 known laminins (for review, see Luckenbill-Edds, 1997; Libby et al., 1999). Thus we postulated that interfering with its synthesis would be maximally effective for the investigation of laminin function in our model. The known exceptions that do not express the $\gamma 1$ chain are laminin 5 (for review, see Luckenbill-Edds, 1997), which contains the $\gamma 2$ chain and is expressed in the basal membrane of blood vessels, and a newly discovered basement membrane-independent group of laminins (numbers 12-15; Libby et al., 1997), which contain a $\gamma 3$ chain (Koch et al., 1999).

In histological sections taken from $\mathrm{P} 4$ hippocampi of normal rats (Fig. $1 A, B)$ a narrow, sickle-shaped pathway of diff use, punctate, immunopositive $\gamma 1$ chain laminin staining was identified beginning in the hilus and extending along the CA3 pyramidal cell body layer (stratum pyramidale). Staining was also present in and around the portion of the apical dendrites closest to the cell body but was lacking entirely in the basal and distalmost portions of the apical dendrites of the young CA3 pyramidal neurons (see also Fig. $2 C$ ). Thus, laminin staining was confined strictly within stratum pyramidale and stratum lucidum, i.e., the identical terrain as the mossy fiber pathway (see O'Keefe and Nadel, 1978; Amaral and Dent, 1981) (see also the schematic in Fig. 6). Interestingly, this staining pattern ended abruptly at the CA3-CA2 border, a point beyond which the mossy fibers did not cross. A higher magnification of this pathway emphasized the diff use but obvious staining of the pyramidal neuron cell bodies that extended into their apical dendrites (Fig. 1B).

A nonradioactive in situ hybridization from freshly prepared $\mathrm{P} 4$ mouse hippocampal sections clearly showed mRNA expression of the $\gamma 1$ chain of laminin in the cell bodies of the CA3 pyramidal neurons (Fig. $2 A$, inset). Laminin mRNA expression was lacking in the CA1 region of the same sections (Fig. $2 B$ ) and was at background levels in the sense controls (data not shown). It is important to clarify that mouse hippocampus was chosen because of the availability of the mouse probe and because axonal plasticity in the hippocampus (Nieto-Sampedro and Bovolenta, 1990) as well as the patterning of laminin protein in the CA3 pyramidal neurons is like that of the rat (W. Halfter, personal communication).

Semithin section (light microscopy; Fig. 2C) and ultrathin section (EM; Fig. 2D,E) examination of immunopositive laminin $\gamma 1$ chain staining of $\mathrm{P} 4$ rat hippocampal slice cultures that had been in vitro overnight revealed three different structures that were associated closely with laminin. Under these conditions and fixation procedures these three were (1) the basal lamina surrounding blood vessels, (2) a dense network of ECM closely associated with the surface of astroglia and at contact points between astroglia in stratum lucidum (Fig. 2E), and (3) small deposits within the cytoplasm and at regions of close membrane contacts of CA3 pyramidal neurons (Fig. 2D). The pyramidal neuron staining visualized in semithin sections was, strikingly, confined to the cell body and clearly within the proximal portion of the apical dendrites in stratum lucidum (Fig. 2C).

These staining patterns, described here in finer detail, are in general agreement with those shown in the publications by Hagg et al. (1997) and Nakagami et al. [(2000), see their Fig. 2]. Such a laminin pathway was also detectable with the use of an antibody against the EHS form of laminin (laminin-1; data not shown). The pyramidal neurons also were stained positively (albeit weakly) with the $\gamma 1$ chain laminin antibody in freshly frozen, unfixed P4 hippocampi, ruling out possible confounding fixation artifacts. Control tissues were soaked in rabbit serum instead of the first antibody and/or visualized by staining with just the Alexa 594 (second antibody). In either case no staining beyond background was seen.

\section{Laminin and neurocan form a pathway with boundaries}

P4 hippocampi were stained simultaneously for laminin and for neurocan that, if positioned appropriately, could provide a potential inhibitory boundary on either side of the laminin pathway (Wilson and Snow, 2000). Strong staining for neurocan was present just peripheral to the pyramidal cell body layer (stratum oriens), a territory that overlaps the basal dendrites of the pyramidal neurons, and in stratum lacunosum (Fig. 1C,D). In general, neurocan staining was relatively lacking where laminin staining was present (Fig. 1D).

\footnotetext{
(Figure legend continued.) with the respective ODN concentrations. In the antisense-treated slice culture no laminin immunoreactivity was observed in the parenchyma $(B)$, but some staining was present around the blood vessels $(B V$; arrow). However, in the mixed base-treated cultures $(A)$ a sickle-shaped pathway of laminin staining can be observed in the pyramidal neurons and stratum lucidum, which foreshadows the mossy fiber pathway. Note the intensely stained cell bodies just distal to the lesion. Staining around the blood vessels (arrowheads) was present and can be used as an internal positive control for the antibody. Scale bar, $100 \mu \mathrm{m}$ ( $D G$, dentate gyrus). Insets in $A$ and $B$ show higher magnifications of equivalent regions just distal to the lesion of the mixed base- and antisense ODN-treated slices. Scale bar, $50 \mu \mathrm{m}$. $C$, The laminin $\gamma 1$ pathway in CA3 in an $0.1 \mu \mathrm{M}$ control DNA enzyme-treated slice that had been in culture for $4 \mathrm{~d}$. Scale bar, $100 \mu \mathrm{m}$. In comparison, $D$ shows the same region in an $0.1 \mu \mathrm{M}$ DNA enzyme-treated slice. In the presence of control DNA enzyme the laminin $\gamma 1$ chain is expressed by the pyramidal neurons; however, such cells are not stained in the DNA enzyme slice. Blood vessel staining was still present. Scale bar, $100 \mu \mathrm{m}$. E, An immunoprecipitation with a monoclonal antibody against the $\gamma 1$ chain of laminin in protein extracts from 12 slice cultures treated for $7 \mathrm{~d}$ with $0.05 \mu \mathrm{M}$ DNA enzyme (DNA enz), $0.05 \mu \mathrm{M}$ control DNA enzyme $(D N A m b), 8 \mu \mathrm{M}$ DNA enzyme, and $8 \mu \mathrm{M}$ control DNA enzyme. The $\gamma 1$ chain has an expected size of $200 \mathrm{kDa}$. In the DNA enzyme-treated protein extracts this band is missing. The control DNA enzyme extracts still contained this band. $F$, The supernatant of the immunoprecipitation shown in $E$ treated with $0.05 \mu \mathrm{M}$ DNA enzyme (DNA enz) and control DNA enzyme $(D N A m b)$ stained with Coomassie blue in an SDS-PAGE gel. $G$, A Western blot for GFAP and $\beta$-actin from the same supernatant.
} 


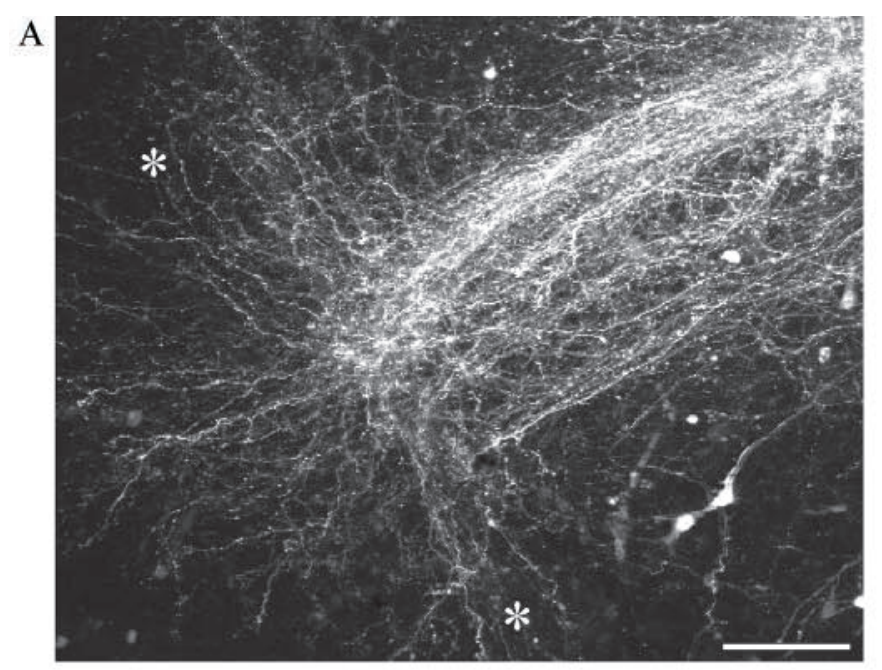

$\mathrm{C}$

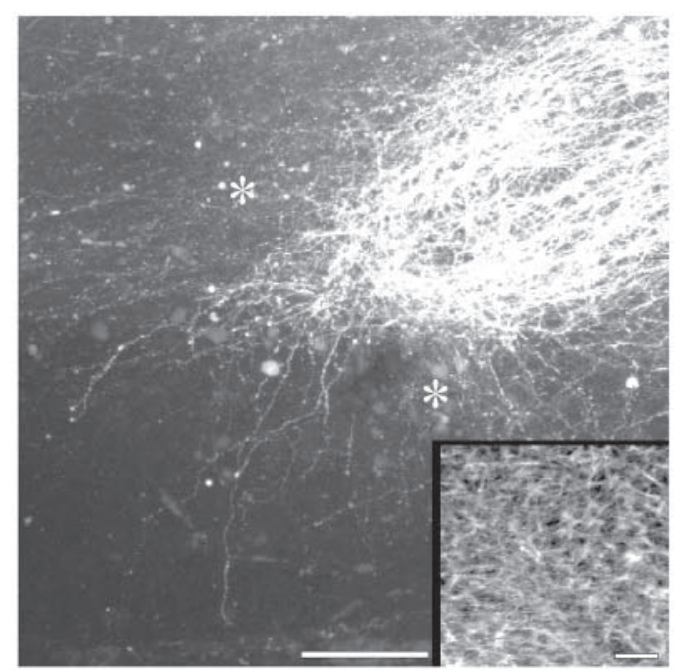

D
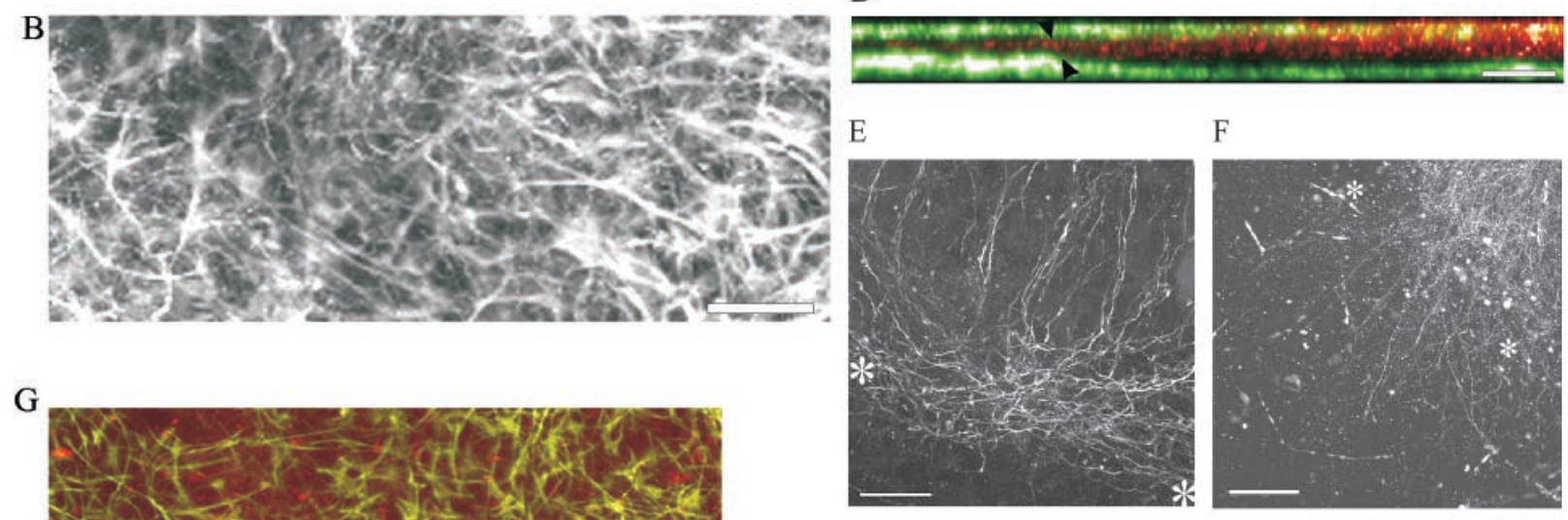

Figure 5. Hippocampal slice cultures treated with antisense ODNs, DNA enzymes, and mixed base ODNs. $A$, Slice culture pretreated with $8 \mu \mathrm{M}$ antisense ODNs for $2 \mathrm{~d}$, lesioned (marked by asterisks), and stained $24 \mathrm{hr}$ later with Micro Ruby. Note the abortive axon regeneration. Scale bar, 100 $\mu \mathrm{m}$. $B$, The GFAP staining of the astrocytes in the lesion site after $24 \mathrm{hr}$. Note that the astrocytes have refilled the lesion. Scale bar, $25 \mu \mathrm{m}$. $C$, DNA enzyme-treated slice $(8 \mu \mathrm{M})$ that was labeled with Micro Ruby after $24 \mathrm{hr}$. Scale bar, $100 \mu \mathrm{m}$. The inset shows the rapid (Figure legend continues.) 


\section{The laminin pattern in the adult hippocampus}

In adult rat hippocampus the expression of the laminin $\gamma 1$ chain was seen distinctly as a system of fine filaments in the cell bodies and proximal portion only of the apical dendrites of the CA3 pyramidal neurons (Fig. $1 E, F)$. The basal dendrites remained unstained. Additionally, in the pyramidal cell body layer, but especially in stratum lucidum, strong globular staining was associated with large numbers of small, irregularly shaped protrusions that emanated from the proximal apical dendrites (Fig. 1G). Such structures resembled dendritic spines and, again, their position overlapped precisely with that of the mossy fiber pathway (Chicurel and Harris, 1992; Harris and Kater, 1994) (see also the schematic in Fig. 6). In adult hippocampus the neurocan staining was reduced, which confirms a previous result of Haas et al. (1999). A higher magnification of the CA3-CA2 border from this adult hippocampus (Fig. $1 H$ ) shows the sudden decrease of laminin $\gamma 1$ chain expression at this location.

\section{The development and lesioning of the mossy projection in slice cultures}

Confocal microscope reconstructions of control P4 hippocampal slice cultures that were unlesioned, untreated, and allowed to develop in situ for $7 \mathrm{~d}$ further and then injected with Micro Ruby in the granule cell layer reveal the origin and entire sickle-shaped route of the mossy fibers (Fig. $3 A$ ). The trajectory of the axons, which passes through the astroglial framework of the slice (Fig. $3 B$ ), does not appear to be foreshadowed by the physical patterning of the glia, which are arranged in a contiguous meshwork that lacks linear organization. The mossy projection that begins in the dentate gyrus as a very tight bundle sometimes can spread out slightly in CA3 (Fig. $3 A$ ). The pattern of immunoreactive laminin $\gamma 1$ chain in hippocampal slices precisely mirrors the route of outgrowth of the mossy fibers (compare Figs. $3 A, 4 A$ ).

Figure $3 C$ is presented to give an overview of the position of the lesion that was used to sever the mossy axons. However, it should be noted that, in slice cultures that are stained with an antibody against the $\gamma 1$ chain of laminin immediately after the lesion, manipulation of the section without any time allowed for normal healing of the wound creates a gap between the cut edges of the tissue.

\section{Immunohistochemical visualization and immunoprecipitation of laminin protein in hippocampal slices after antisense ODN and DNA enzyme treatment} In our experiments we treated hippocampal slice cultures with a variety of concentrations of antisense, mixed base (control) ODNs, DNA enzyme, and mixed base (control) DNA enzyme from 0.05 to $8 \mu \mathrm{M}$. These concentrations have been accepted as being within an optimal range by many other labs (Leslie et al., 1999). In all cases the effects on axon regeneration were mainly equivalent. In the description of the results that follows, representative data of selected concentrations are shown. However, for a complete analysis of the full range of the experiments, see Table 1 for quantitative data.

P4 hippocampal slice cultures treated with $0.1 \mu \mathrm{M}$ antisense, 0.1 $\mu \mathrm{M}$ mixed based (control) ODN, $0.1 \mu \mathrm{M}$ DNA enzyme, or $0.1 \mu \mathrm{M}$ control (mixed base) DNA enzyme for $2 \mathrm{~d}$ were lesioned and maintained in culture for $1-5 \mathrm{~d}$ more in the continued presence of these reagents (Fig. $4 A-D$ ). The numbers of laminin $\gamma 1$ chain stained blood vessels had declined in all of these slices (i.e., control and antisense ODNs as well as DNA enzymes). This is likely attributable, in large part, to breakdown of the vasculature, which occurs normally within the slice. However, a few stained vessel basal laminas were still visible in all slices, which suggests that laminin within the basal lamina may be especially stable. In the control antisense and control DNA enzyme-treated slices, densely stained laminin-positive cells and their processes persisted in the pyramidal and lucidum layers for the length of the experiment (Fig. 4A,C, inset). The stained cells formed a sickleshaped pathway that closely resembled that which was described in normal postnatal hippocampal tissues and that also resembles the route taken by normal as well as regenerating axons in the control slices (see below; compare Figs. 1, 4A). However, importantly, neither in the antisense ODN-treated slice cultures (Fig. $4 B$, inset) nor in the DNA enzyme-treated slices (Fig. 4D) was such a pathway of nonbasal lamina laminin detectable by immunohistochemistry.

To add further confidence to the immunohistochemical data, we performed an immunoprecipitation of the $200 \mathrm{kDa}$ laminin $\gamma 1$ chain with the same antibody used for the immunostaining. In these studies we focused on and compared slices that were treated with DNA enzyme and control DNA enzyme. In these studies DNA enzyme or control DNA enzyme at a concentration of 0.05 or $8.0 \mu \mathrm{M}$ was added to P4 slices for $7 \mathrm{~d}$. The slices had been lesioned on day 2. Immunoprecipitation showed a lack of the 200 $\mathrm{kDa}$ band in the DNA enzyme-treated slices (Fig. $4 E$ ). In contrast, the control DNA enzyme-treated slices showed a strong positive band at $200 \mathrm{kDa}$ (Fig. $4 E$ ). To make certain that the same amount of protein was loaded, we applied $10 \mu \mathrm{l}$ of the same supernatant that was left over from the immunoprecipitation to an SDS-PAGE gel and stained it with Coomassie blue (Fig. 4F). Many comparably stained bands confirmed that equal amounts of total protein were present in each lane. To ascertain whether several selected proteins were still present that are unrelated to laminin, but for which the presence is indicative of the specificity of treatment as well as the overall health of the DNA enzymetreated cultures, we showed that GFAP and $\beta$-actin were at comparable levels (Fig. 4G).

\section{Inhibition of regeneration of the mossy fibers in DNA enzyme- and antisense-treated organotypic hippocampal slices}

Slices that were pretreated for $2 \mathrm{~d}$ with mixed base (control) or antisense ODNs against the $\gamma 1$ chain of laminin then were lesioned and allowed to develop for as little as 1 or as long as $5 \mathrm{~d}$ more (i.e., up to a total of $7 \mathrm{~d}$ in situ). In the continued presence of control ODNs the mossy fiber pathway regenerated robustly. Figure $5 G$ demonstrates the exceptional speed of regeneration in a control slice that had been treated with $8 \mu \mathrm{M}$ mixed base ODN

(Figure legend continued.) infiltration of the lesion with astrocytes. Note the abortive axon regeneration. Scale bar, $50 \mu \mathrm{m} . D$, The cross-sectional $(x-y)$ location of the mossy fibers shown in $x-z$ orientation in $A$ (mossy fibers, red; astrocytes, green). Arrowheads indicate the position of the lesion. Scale bar, $50 \mu \mathrm{m}$. E, A hippocampal slice culture treated with $2 \mu \mathrm{M}$ antisense ODN for $5 \mathrm{~d}$ after lesion. Scale bar, $25 \mu \mathrm{m}$. $F$, A slice culture treated with $8 \mu \mathrm{M}$ DNA enzyme for $5 \mathrm{~d}$ after lesion. Scale bar, $100 \mu \mathrm{m}$. $G$, A control hippocampal slice culture that was pretreated with $8 \mu \mathrm{M}$ mixed base ODNs $2 \mathrm{~d}$ before being transected and allowed to regenerate for $1 \mathrm{~d}$ after the lesioning. The culture was injected with Micro Ruby (red) to label the regenerated mossy fibers and stained with GFAP antibodies to label the astrocytes (green). The lesion is marked by asterisks. Scale bar, $100 \mu \mathrm{m}$. 
and allowed to regenerate for $24 \mathrm{hr}$. Indeed, the regrowing axons had the capacity to elongate approximately three-fourths of the way to the end of their pathway in just $1 \mathrm{~d}$. Unlike untreated uncut slices (Fig. 3A), mixed base-treated lesioned slices showed a broadening of the fibers as they passed through the hilus as well as a slight contortion of the typical hook shape. It is noteworthy, however, that both of these variations, which likely are caused by misalignment of the stratum lucidum after the lesion, can be typical of hippocampal slices that are allowed to regenerate. The DNA enzyme controls (DNA mixed base, $8 \mu \mathrm{M}$ ) also regenerated and were comparable with the antisense mixed base control slices (data not shown).

Treatment of P4 slices for $2 \mathrm{~d}$ with $8 \mu \mathrm{M}$ antisense ODN to the $\gamma 1$ chain of laminin, followed by transection and further treatment for 1 or $5 \mathrm{~d}$ additionally in culture (i.e., up to $7 \mathrm{~d}$ total), led to a dramatic diminution in the number of regenerating axons as well as a remarkable change in the anatomical pattern of axon regeneration that typically occurs in the lesioned slice (Fig. 5A,E). Importantly, regeneration was mainly abortive in slices treated with concentrations of this potent reagent as low as $0.05 \mu \mathrm{M}$ (see Table 1 ). Thus as early as $1 \mathrm{~d}$ (Fig. $5 A$ ) or as late as $5 \mathrm{~d}$ after lesion (Fig. $5 E$ ) the vast majority of the regenerating mossy fibers could not cross the injury site. They did regenerate, albeit slowly, within and along the lesion itself where the fibers appeared to fasciculate with each other (Fig. 5E). Axonal surfaces are an excellent substrate for regeneration, because they carry various growthpromoting adhesion molecules such as L1, neural cell adhesion molecule (NCAM), and N-cadherin (Walsh and Doherty, 1997; Woolhead et al., 1998). Importantly, a small but significant number of axons did navigate across the lesion successfully. However, once beyond the lesion these fibers also grew poorly in comparison to those in the lesioned mixed base-treated slices (compare Fig. $5 G$ with $A$ ), and they took an uncontrolled and meandering course that was not at all confined to stratum lucidum or stratum pyramidale.

Treatment of lesioned hippocampal slices that used the $2+1 \mathrm{~d}$ treatment regimen with $8 \mu \mathrm{M}$ DNA enzyme caused a lack of regeneration that was essentially identical in pattern to that caused by antisense (Fig. 5C,F). Similar to the antisense experiments, in the presence of DNA enzyme directed against the $\gamma 1$ chain of laminin, the mossy fibers, although mainly unable to regenerate within stratum lucidum or stratum pyramidale, did continue to elongate, albeit slowly and haphazardly beyond, within, and on the proximal side of the lesion.

To provide a measure of confidence in regard to completeness of the transection in every slice, confocal scans along the $x-y$-axis (Fig. $5 A$ )were rotated along the $x-z$-axis. As shown in Figure $5 D$, mossy fibers both proximal and distal to the lesion site were always in the middle of the slice [a typical appearance for the organotypic hippocampal slice culture (Buchs et al., 1993)] and never along the bottom where they would be expected to reside if the scalpel blade had pushed some fibers downward but had allowed for sparing.

\section{Quantification of the amount and length of axon regeneration in antisense and mixed base-treated hippocampal slices}

The results of treatment for $5 \mathrm{~d}$ after lesion (i.e., $2+5 \mathrm{~d}$ regimen) with five different concentrations of antisense ODNs ( 0.05 to 8 $\mu \mathrm{M})$ are shown in Table 1 and Figure 6. Measuring the lengths of individual mossy fibers is difficult because they are very thin and intertwined. Therefore, pixel intensity measurements of Micro

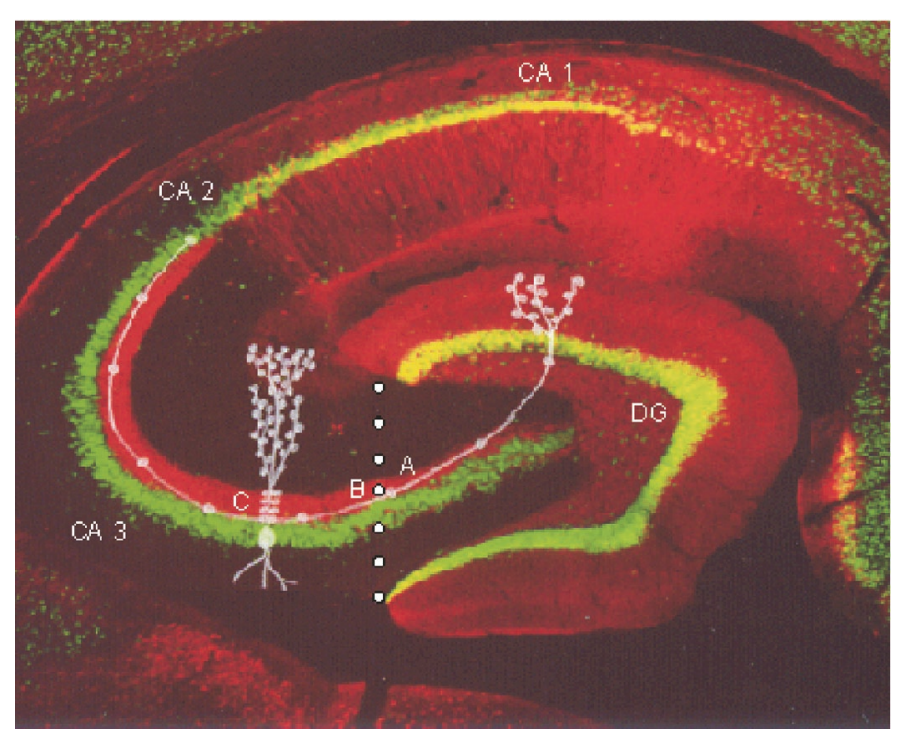

Figure 6. This figure is a composite of a schematic drawing adapted from O'Keefe and Nadel (1978) and a double immunohistochemical stain of a section of the hippocampus kindly reproduced with permission from Dr. Daniel Peterson and Current Opinion in Pharmacology [portion of a figure on the cover (2002)]. The green neuron cell bodies are stained with Neu $\mathrm{N}$ antibodies, and the mossy fibers among others have been stained red with calbindin antibodies. The schematic depicts an adult granule neuron in the dentate gyrus that extends a mossy fiber within the stratum lucidum (tight red bundle) to the border of CA3-CA2. A typical pyramidal neuron also is drawn to show that the mossy fiber projection within the stratum lucidum intersects only with a restricted portion of the proximal apical dendrite. Additionally, this picture shows the locations at which axonal densities were quantified. $A$ is proximal to the lesion (measure point 1 ); $B$ is distal to the lesion (measure point 2); $C$ is $190-230 \mu \mathrm{m}$ distal to point $B$ (measure point 3 ). Point $A$ is in the dentate gyrus; points $B$ and $C$ are in the CA3 region. The lesion is shown by white dots.

Ruby-labeled axons from such slice cultures were made at three positions: (A) just proximal, (B) just distal, and (C) 190-230 $\mu \mathrm{m}$ distal to lesion sites in the hilar portion of CA3 (Fig. 6). To standardize our measurements to account for interslice variability, we considered the proximal measurement in the dentate to be the $100 \%$ determination (see Table 1, position A). The two distal measurements (positions $\mathrm{B}$ and $\mathrm{C}$ in Table 1) were expressed as percentages of the proximal measurement for each slice. The furthest measurement from the lesion (position $\mathrm{C}$ ), which was $190-230 \mu \mathrm{m}$ from the lesion, was chosen because it is a position in which significant numbers of axons can regenerate in all controls. The quantitation showed that, at position B just distal to the lesion, mixed base-treated slices had a higher regeneration rate (49-94\%) than antisense-treated slices (20-35\%). In addition, at the longer distance (position C) all mixed base-treated hippocampal slices showed a clear regeneration rate of 19-30\%. However, in the antisense-treated cultures the vast majority of fibers had fallen considerably short of the greater distance; thus the quantitative measurements at point $\mathrm{C}$ were essentially at background levels. Considering all 30 slice cultures treated with all concentrations of antisense ODNs (Table 1), in only two of these 30 slices at one of the lowest concentrations $(0.1 \mu \mathrm{M})$ there was one lone fiber per slice that grew significantly. Thus in one treated slice a single mossy fiber reached the distance of $190 \mu \mathrm{m}$, and in the other slice a single fiber reached nearly $250 \mu \mathrm{m}$.

In the DNA enzyme-treated and control DNA enzyme-treated slices, axon lengths were not quantified. However, it was clear that the failure of regeneration brought about by the DNA enzyme 


\begin{tabular}{|c|c|c|c|c|c|}
\hline $\begin{array}{l}\text { Mixed base } \\
\text { concentration }(\mu \mathrm{M})\end{array}$ & $\begin{array}{l}\text { Number of slices showing } \\
\text { axon regeneration }\end{array}$ & $\begin{array}{l}\text { Number of slices showing } \\
\text { limited axon regeneration }\end{array}$ & $\begin{array}{l}\mathrm{Reg} / \mathrm{SD} \\
\text { point } b \times 100 \\
\text { point a }(\%)\end{array}$ & $\begin{array}{l}\mathrm{Reg} / \mathrm{SD} \\
\text { point } c \times 100 \\
\text { point a }(\%)\end{array}$ & Total number of slices \\
\hline 0.05 & 4 & 1 & $49.7 / 22.4$ & 19.6/14.3 & 5 \\
\hline 0.1 & 4 & - & $77.8 / 29.9$ & $30.6 / 18.4$ & 4 \\
\hline 0.5 & 5 & 1 & $81.4 / 27.6$ & 19.3/7.0 & 6 \\
\hline 2 & 3 & - & $73.7 / 26.0$ & 28.5/13.6 & 3 \\
\hline 8 & 3 & - & $94.4 / 12.8$ & $47.3 / 24.1$ & 3 \\
\hline $\begin{array}{l}\text { Antisense } \\
\text { concentration }(\mu \mathrm{M})\end{array}$ & $\begin{array}{l}\text { Number of slices showing } \\
\text { axon growth inhibition }\end{array}$ & $\begin{array}{l}\text { Number of slices showing } \\
\text { some axon regeneration }\end{array}$ & $\begin{array}{l}\text { Reg/SD } \\
\text { point } b \times 100 \\
\text { point a }(\%)\end{array}$ & $\begin{array}{l}\mathrm{Reg} / \mathrm{SD} \\
\text { point } c \times 100 \\
\text { point a }(\%)\end{array}$ & Total number of slices \\
\hline 0.05 & 7 & 2 & $24.6 / 9.3$ & $\mathrm{Bkg}$ & 9 \\
\hline 0.1 & $8^{*}$ & 1 & $35.1 / 18.3$ & * & 9 \\
\hline 0.5 & 3 & 1 & $20.2 / 7.6$ & $\mathrm{Bkg}$ & 4 \\
\hline 2 & 5 & - & $28.8 / 11.0$ & $\mathrm{Bkg}$ & 5 \\
\hline 8 & 3 & - & $23.6 / 8.3$ & $\mathrm{Bkg}$ & 3 \\
\hline
\end{tabular}

Bkg, Background; Reg, regeneration. *In two slices from this group one mossy fiber per slice grew a relatively long distance (see Results).

was qualitatively equivalent to the antisense- and mixed base ODN-treated slice cultures (compare Fig. $5 A$ with $C$ ).

\section{Astroglial cells at the lesion site}

Astrocytes completely repopulate the 50-100 $\mu \mathrm{m}$ wide gap created by the scalpel blade within the first day after injury (Fig. $5 B, C$, inset in $C, G)$. Also, an aerial view of the overall shape of the astrocyte network (Fig. $5 G$ ) within the slice was neither predictive of where the laminin pathway was being expressed nor where the future route of mossy fiber regeneration would be (compare Figs. 4A, 5G). Importantly, in control slices the regenerating axons did not wander as they crossed the lesion site. Therefore, the lesion itself did not appear to be even a minimal barrier to the regenerating axons (Fig. 5G). Comparisons between the antisense- or DNA enzyme-treated slice cultures and their respective controls at all concentrations revealed that the shapes of the astrocytes throughout the slice and the rate at which astrocytes invaded the lesion gap were equivalent. Additionally, the levels of GFAP protein in DNA enzyme- and control DNA enzyme-treated slices were comparable when analyzed by Western blot analysis of SDS-PAGE (Fig. 4G).

\section{Regrowth of the mossy fibers after termination and washout of antisense ODNs and DNA enzymes}

This "recovery" experiment was undertaken to investigate further whether (1) the hippocampal slice cultures were in relatively good health and (2) whether they had the ability to regenerate (i.e., delayed regeneration) after the antisense ODNs or DNA enzymes were washed away.

Slice cultures of $\mathrm{P} 4$ rats were treated with $8 \mu \mathrm{M}$ antisense ODNs or DNA enzyme for $2 \mathrm{~d}$. Early in the morning of day 3 the slice cultures were lesioned and treated for $1 \mathrm{~d}$ more. On days 4-7 in culture, antisense or DNA enzyme treatment was stopped, and fresh medium was added. Thus, after a total of $7 \mathrm{~d}$ in culture the mossy fibers were labeled with Micro Ruby (Fig. 7A,B). In such antisense ODN- and DNA enzyme-treated/washout slice cultures the mossy fibers did, indeed, show a renewed burst of regeneration across the lesion site. Furthermore, the regrowing axons displayed a strong tendency to travel within strata lucidum and pyramidale. The lesion was not readily visible because astrocytes invaded and refilled the lesion completely (Fig. 7C,E). Therefore, antisense or DNA enzyme treatment (at least for $3 \mathrm{~d}$ ) did not appear to cause overt or irreversible harm to the mossy fibers, nor did the treatments appear to inflict damage to the glia or cause permanent damage to the pyramidal neurons that again were able to upregulate the production of laminin (Fig. 7D).

\section{An analysis of the effects of antisense ODNs and DNA enzymes on mRNA levels}

Neither of the concentrations of antisense ODNs $(0.05$ or $8 \mu \mathrm{M})$ produced a significant compensatory increase or decrease in laminin $\gamma 1$ chain mRNA expression when analyzed via RT-PCR/ Southern blot techniques. Therefore, the antisense-treated slice cultures did not appear to upregulate mRNA production to compensate for the missing $\gamma 1$ chain of laminin (Fig. $8 A$ ). However, when the DNA enzyme-treated slices were analyzed in the same manner, specific digestion of the laminin $\gamma 1$ chain mRNA was seen (Fig. 8C). The specificity of the DNA enzyme reaction was shown by comparing a closely related mRNA for the laminin $\beta 2$ chain, which was unaltered (Fig. $8 E$ ). As a control for loading equal amounts of mRNA, $\beta$-actin mRNA was used in all cases (Fig. 8B,D).

\section{DISCUSSION}

In the present study we have focused on the question of whether a well described pathway of cells and extracellular matrix containing the $\gamma 1$ chain of laminin plays a critical role in support of CNS axon regeneration. To answer this question, we performed experiments with the use of cultured hippocampal slices because they retain much of the circuitry of the intact hippocampus and because in situ (as well as in vivo) the mossy fibers exhibit a profound capacity for compensatory sprouting (Altman and Das, 1965; Laurberg and Zimmer, 1981; Eckenhoff and Rakic, 1988; Eriksson et al., 1998; Mizuhashi et al., 2001) as well as regeneration (Zimmer and Gähwiler, 1987; Li et al., 1994; Nguyen et al., 1996; Eriksson et al., 1998). In the in situ model the mossy fibers can regenerate vigorously across a spontaneously repaired line of damage and along their proper pathway. This phenomenon may bear certain similarities to forms of reactive gliosis that are not 
A

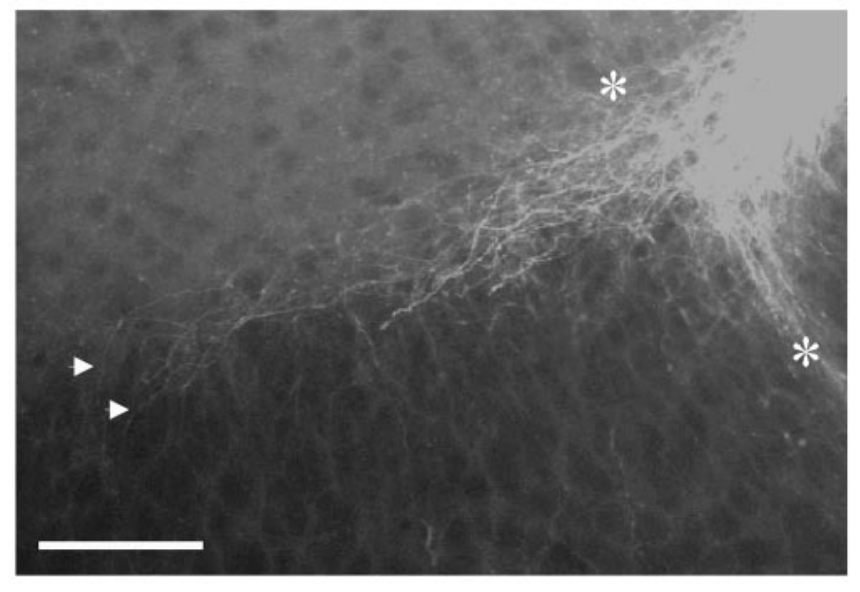

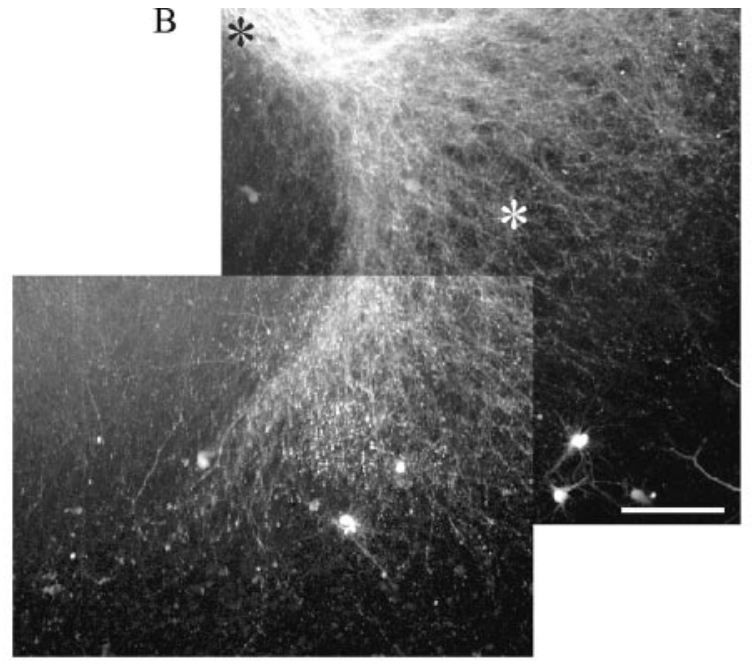

$\mathrm{C}$

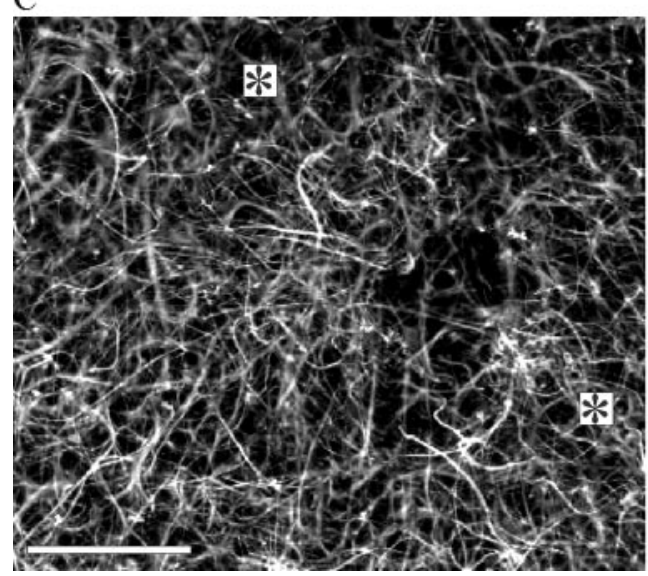

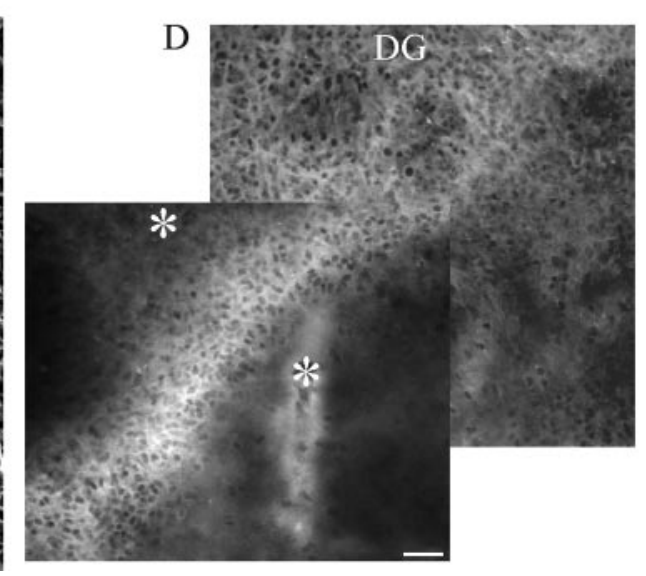

E

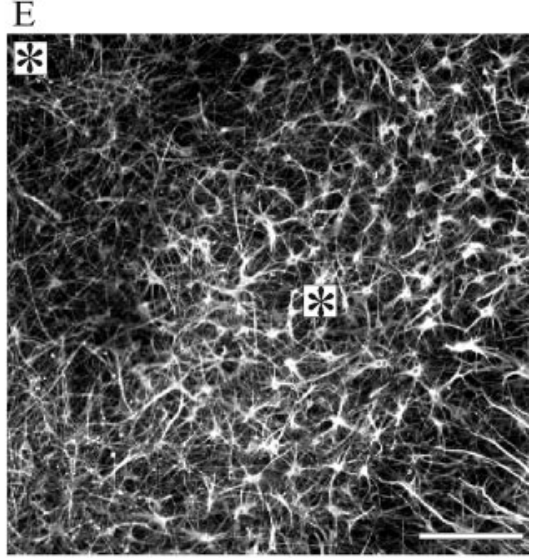

Figure 7. Recovery of the mossy fibers and reinitiated regeneration after washout of antisense ODNs and DNA enzyme in treated hippocampal slice cultures. $A$, A slice culture treated with $8 \mu \mathrm{M}$ antisense ODN for $3 \mathrm{~d}$ and then lesioned (marked by asterisks), followed by a washout of the antisense ODNs and no treatment for $5 \mathrm{~d}$ further. The mossy fibers regrow along their expected pathway. The ends of the mossy fibers are marked by arrowheads. $B$, Renewed axon regeneration in a slice culture treated with $8 \mu \mathrm{M}$ DNA enzyme for $3 \mathrm{~d}$ and lesioned (marked by asterisks), followed by a washout of the DNA enzyme and no treatment for $5 \mathrm{~d}$ further. $C$, GFAP staining around the lesion shown in $A$. The area of the lesion is marked with asterisks. $D$, The re-expression of the $\gamma 1$ chain of laminin in an $8 \mu \mathrm{M}$ antisense-treated slice culture. The slice had been treated for $3 \mathrm{~d}$ and lesioned (marked by asterisks), followed by a washout of the antisense ODN and no treatment for $5 \mathrm{~d}$ further ( $D G$, dentate gyrus). $E$, The respective astrocyte staining of $B$ around the lesion (marked by asterisks). Scale bars, $100 \mu \mathrm{m}$.

associated with scar formation and allow for sprouting or regeneration in vivo (Altman and Das, 1965; Kaplan and Hinds, 1977; Raisman, 1985; Smith et al., 1986; Chauvet et al., 1995; Kuhn et al., 1996). In the laminin antisense ODN- and DNA enzymetreated hippocampal slice cultures, although astroglial healing of the lesion site as well as overall glial patterning throughout the slice were unaffected, regrowth of the vast majority of mossy fibers was disallowed.

Thus, our data demonstrate for the first time a critical role for laminin(s) in an early postnatal regeneration model of the CNS that takes place in the context of a complicated array of interacting glial and neuronal cell types. Laminin that is embedded in the basal lamina of blood vessels is unlikely to play a role in axon regeneration in this model because its lacks appropriate spatial prepatterning and because vessel basal lamina is enwrapped by other molecules such as proteoglycans and collagens that are mainly nonpermissive to axon outgrowth (Burg et al., 1996; Joosten et al., 2000). The two additional forms of laminin (astrocyte and neuron-associated) within this specialized portion of the
CNS that could play a more obvious role in regeneration appear to be present in several different patterns and in tissue compartments both inside and outside of cells. Whether one or both of these basal lamina-independent types is responsible for axon regeneration is a matter of speculation, because both were reduced or eliminated during treatment. Therefore, we still do not know for certain which cell type or types express the axon regeneration-promoting form of laminin, nor do we know which form of laminin permits such robust regeneration to occur. Nonetheless, the precise spatiotemporal correlation that exists between regenerating granule cell mossy fibers and restricted portions of the CA3 pyramidal neurons that contain laminin protein as well as laminin $\gamma 1$ chain mRNA does lead us to suggest that a causal relationship mediated by laminin must exist between these two neuronal partners.

Laminin deposits along a filamentous network within the cell bodies and continuing into a restricted portion of the apical dendrites of CA3 pyramidal neurons (Fig. 2C) have not been described previously, although Hagg et al. (1989) did suggest that 
A

$$
\begin{array}{ll}
\sum_{3} & \vdots \\
1 & 0 \\
0 & 0 \\
0 & 0 \\
\text { ปै } & \text { है }
\end{array}
$$

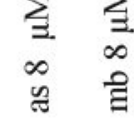

$506 \mathrm{bp}$
$396 \mathrm{bp}$

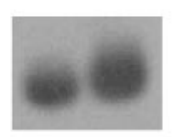

$\operatorname{Laminin} \gamma 1$
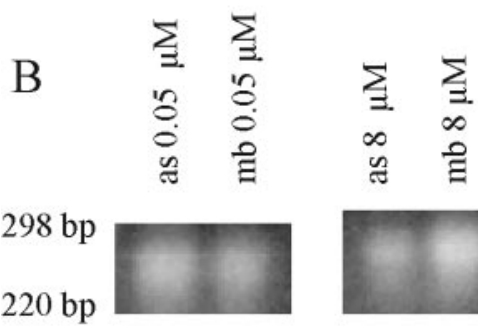

\section{$\beta$-Actin}

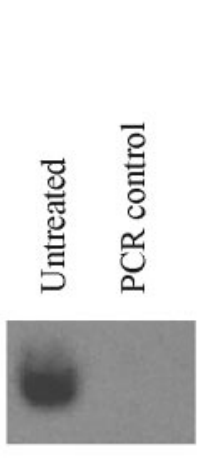

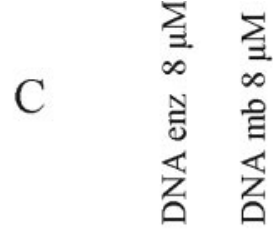

$506 \mathrm{bp}$

396 bp

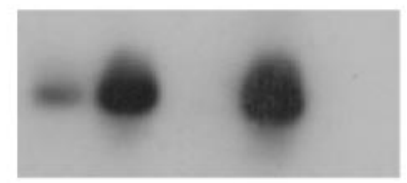

Laminin $\gamma 1$

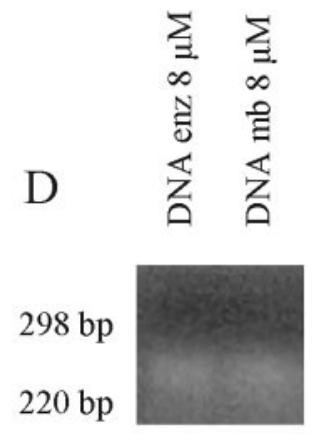

$\beta$-Actin
Figure 8. RT-PCR analyses from RNA preparations taken from untreated slices as well as from slices treated with antisense (as), mixed base ODNs $(\mathrm{mb})$, DNA enzyme (DNA enz), and mixed base DNA enzyme (DNA $m b)$. The slices (treated and untreated) were maintained in culture for $7 \mathrm{~d}$ for antisense and mixed base ODNs and for $4 \mathrm{~d}$ for DNA enzyme and control DNA enzyme. $A$, RT-PCR Southern blot for the $\gamma 1$ chain of laminin after antisense and mixed base ODN treatment (expected RT-PCR product size, $450 \mathrm{bp}$ ). $B$, Agarose gel of an RT-PCR for $\beta$-actin mRNA from the same preparations shown in $A$ (expected RT-PCR product size, $260 \mathrm{bp}$ ). Note that the laminin $\gamma 1$ chain mRNA shows only minimal changes, which are repeated in the size of the actin bands. $C$, RT-PCR Southern blot for the $\gamma 1$ chain of laminin from slice cultures treated with DNA enzyme showing a reduction of $\gamma 1$ chain mRNA compared with slices treated with control DNA enzyme (expected RT-PCR product size, $450 \mathrm{bp}$ ). $D$, Agarose gel of an RT-PCR for $\beta$-actin mRNA from the same preparation as shown in $C$ (expected RT-PCR product size, $260 \mathrm{bp}$ ). $E$, The use of the same preparation as in $C$ for an RT-PCR of the laminin $\beta 2$ chain (expected RT-PCR product size,

$349 \mathrm{bp})$. This related chain to the $\gamma 1$ chain of laminin is not affected by the DNA enzyme treatment. The PCR control is an RT-PCR without RNA but with all buffers to check for contamination.

hippocampal laminin was present at synapses. The role of laminin in the development and function of synapses on hippocampal pyramidal neurons is now under investigation by other labs where it has been shown that laminin may be involved with the regulation of long-term potentiation (Nakagami et al., 2000). It also is known that laminin has a strong organizing effect on the formation of point contacts and integrin clustering, which occur along the surfaces of axonal growth cone filopodia (Schmidt et al., 1995; Renaudin et al., 1999). In addition, laminin has been shown to have prominent enhancing effects on the motility of dendritic spines (Seil, 1998) for which the dynamic interactions with axonal growth cone filopodia may be essential during axonal outgrowth and synapse formation (Tsui et al., 1985; Halfter, 1996; Wu et al., 1999; Jontes and Smith, 2000; Korkotian and Segal, 2001; Prange and Murphy, 2001). It may be that pyramidal cell laminin, if transported and/or secreted locally within the vicinity of developing proximal spines [i.e., the so-called thorny excrescences, Gonzales et al. (2001) and Amaral and Dent (1981), see their Fig. 5], may play a critical role in stimulating exploratory behaviors by fine caliber dendritic protrusions for which the role may be to lure mossy fiber growth cone filopodia toward their surfaces. It is fascinating to consider the possibility that the highly restricted pathway of laminin on the apical dendrites of CA3 pyramidal neurons would place a potent axon regeneration-promoting molecule at the very doorstep of potential synaptic sites between regenerating mossy fiber terminals and their specific postsynaptic partners, a remarkably pinpointed distribution, indeed.

Laminin can be localized to focal contacts between glia and other non-neuronal cells or more diffusely in the extracellular matrix where it is represented by an immunoreactivity that is distributed in fine punctate deposits (Liesi and Silver, 1988). It has been demonstrated repeatedly that extracellular astroglial matrices, in vitro, are axon growth-supportive, at least in part, because of laminin (Manthorpe et al., 1983; Liesi and Risteli, 1989; Smith et al., 1990; Wujek et al., 1990; Groves et al., 1993; Tomaselli et al., 1993; Garcia-Abreu et al., 1995). However, the presence and/or function of this diffuse form of laminin, in vivo, have been extremely controversial. Indeed, only a few groups of researchers have been able to visualize the extracellular punctate form of laminin within the brain parenchyma (Letourneau et al., 1988; Liesi and Silver, 1988; McLoon et al., 1988; Gordon-Weeks et al., 1989; Liesi and Risteli, 1989; Zhou, 1990; Cohen and Johnson, 1991). Now a number of labs clearly have revealed a diff use, punctate laminin immunoreactivity in the stratum lucidum and area CA3 of the P4 hippocampus (Hagg et al., 1989, 1997; Zhou, 1990; Nakagami et al., 2000; this study). The extracellular location of laminin, which was confirmed here by EM, suggests the possibility that axon guidance information may be generated by the expression of certain forms of this family of ECM molecules that develop within confined macroscopic highways.

Abundant quantities of laminin in the extracellular space of stratum lucidum not only may stimulate regenerating axons as they navigate through this region but also may be involved with interactions between the glia and/or between glia and neurons that are critical in the assembly or maintenance of the threedimensional geometry of the glial/neuronal scaffold (Willbold et al., 2000). Perhaps laminin is involved with specialized astroglial movements (e.g., axon-enwrapping or channel-forming behaviors) that are critical as axonal growth cones pass over their membranes (Smith et al., 1986; Payne and Lemmon, 1993; Isacson et al., 1995). Such movements may help to allow for some form of structural plasticity that occurs amid a denser and more rigid cellular backbone of tissue. Although it is clear that laminin antisense ODN and DNA enzyme treatment did spare gross glial 
architecture while severely altering axon regeneration, we cannot rule out the possibility that subtle glial movements in association with axonal regeneration were altered.

\section{Is laminin the only regeneration-promoting molecule in the hippocampus?}

Although reduction of laminin expression by using antisense ODN and DNA enzyme technology curtails the vast majority of regenerating mossy fibers, a small number of mossy fibers can grow across the lesion, at least for short distances. The simplest explanation for the incomplete effect on regeneration is that antisense ODNs and even DNA enzymes do not eliminate $100 \%$ of laminin expression or that laminin degradation is not fully complete at the time these fibers cross the lesion. Another possibility is that reduction of $\gamma 1$ subunit expression produces an upregulation of another laminin subunit (i.e., other than $\beta 2$, such as $\alpha 5$ and $\gamma 3$, which have also been identified in the CNS; W. Brunken, personal communication) that compensates for the loss of $\gamma 1$ (Libby et al., 1997, 1999; Patton et al., 1997). Also, although we have manipulated specifically the expression of the $\gamma 1$ chain of laminin, it would be premature to claim that the effects on axon outgrowth are mediated solely or directly by laminin. For example, the loss of laminin could affect indirectly the function of other molecules. Laminin is known to bind to heparan sulfate proteoglycans such as syndecan, agrin, and perlecan, which, in turn, can bind a variety of growth factors and neurotropic molecules (Olsen, 1999). Future experiments in which integrin expression in granule cell neurons is reduced by using DNA enzymes and antisense ODNs will help to clarify the possibility of a direct role for laminin in CNS axon outgrowth and regeneration. In addition to laminin, a number of other axon guidance molecules, including netrin-1 (Mitchell et al., 1996; Steup et al., 2000), polysialylated NCAM (Seki and Arai, 1991; Seki and Rutishauser, 1998; Cremer et al., 2000), and L1 (Miller et al., 1993; Wong et al., 1995), are expressed in the hippocampus and could affect mossy fiber regeneration. However, they do not appear to be capable of compensating in a major way for the lost members (either bound or soluble forms) of the laminin family during regeneration.

\section{Why does the hippocampus maintain a pathway that expresses such high concentrations of a potently growth-supporting form of laminin?}

Evidence exists that small populations of neurons continue to be born, fully mature, and to elaborate axons (van Praag et al., 2000) in the adult hippocampus (Eckenhoff and Rakic, 1988; Eriksson et al., 1998). The newly born neurons originate from putative stem cells that exist in the subgranular zone of the dentate gyrus (Eriksson et al., 1998; Seri et al., 2001). Progeny of these immature cells differentiate into neurons in the granule cell layer within a month of their birth. This late form of neurogenesis and axon growth continues throughout the adult life of the rodent (Gage et al., 1995) as well as humans (Eriksson et al., 1998). The critical question arises: Does the laminin pathway in the hippocampus continue to exist to provide for de novo formed hippocampal neurons their differentiation signals as well as a guidance highway for their axons? Transplantation experiments that use stem cells precisely delivered within the territory of the normal or perturbed laminin pathway will help to address this question.

In conclusion, our experiments have demonstrated a critical role for laminin(s) in directing mossy fiber regeneration. Given the potent effects of laminin on promoting the outgrowth of CNS axons in the regenerating hippocampus, it is possible that the particular format in which laminin is found in this specialized region of the brain also may be used in a strategy for stimulating the regeneration of other severed axons, such as those in the spinal cord, which fail to regenerate after injury.

\section{REFERENCES}

Altman J, Das GD (1965) Autoradiographic and histological evidence of postnatal hippocampal neurogenesis in rats. J Comp Neurol 124:319-335.

Altschul SF, Madden TL, Schaeffer AA, Zhang J, Zhang Z, Miller W, Lipman DJ (1997) Gapped BLAST and PSI-BLAST: a new generation of protein database search programs. Nucleic Acids Res 25:3389-3402.

Amaral DG, Dent JA (1981) Development of the mossy fibers of the dentate gyrus. I. A light and electron microscopic study of the mossy fibers and their expansions. J Comp Neurol 195:51-86.

Asher RA, Morgenstern DA, Fidler PS, Adcock KH, Oohira A, Braistead JE, Levine JM, Margolis RU, Rogers JH, Fawcett JW (2000) Neurocan is upregulated in injured brain and in cytokine-treated astrocytes. J Neurosci 20:2427-2438.

Bonner J, O'Connor TP (2001) The permissive cue laminin is essential for growth cone turning in vivo. J Neurosci 21:9782-9791.

Buchs P-A, Stoppini L, Muller D (1993) Structural modifications associated with synaptic development in area CA1 of rat hippocampal organotypic cultures. Brain Res Dev Brain Res 71:81-91.

Burg MA, Tillet E, Timpl R, Stallcup WB (1996) Binding of the NG2 proteoglycan to type VI collagen and other extracellular matrix molecules. J Biol Chem 271:26110-26116.

Burgeson RE, Chiquer M, Deutzmann R, Ekblom P, Engel J, Kleinmann H, Martin GR, Meneguzzi G, Paulson M, Sanes J, Timpl R, Tryggvason K, Yamada Y, Yurchenco PD (1994) A new nomenclature for the laminins. Matrix Biol 14:209-211.

Calof AL, Campanero MR, O'Rear JJ, Yurchenco PD, Lander AD (1994) Domain-specific activation of neuronal migration and neurite outgrowth-promoting activities of laminin. Neuron 13:117-130.

Canning DR, Hoke A, Malemud CJ, Silver J (1996) A potent inhibitor of neurite outgrowth that predominates in the extracellular matrix of reactive astrocytes. Int J Dev Neurosci 14:153-175.

Chauvet N, Parmentier ML, Alonso G (1995) Transected axons of adult hypothalamo-neurohypophysial neurons regenerate along tanycytic processes. J Neurosci Res 41:129-144.

Chicurel ME, Harris KM (1992) Three-dimensional analysis of the structure and composition of CA3 branched dendritic spines and their synaptic relationships with mossy fiber boutons in the rat hippocampus. J Comp Neurol 325:169-182.

Cohen J, Johnson AR (1991) Differential effects of laminin and merosin on neurite outgrowth by retinal ganglion cells. J Cell Sci Suppl 15:1-7.

Cornbrooks CJ, Carey DJ, McDonald JA, Timpl R, Bunge RP (1983) In vivo and in vitro observation on laminin production by Schwann cells. Proc Natl Acad Sci USA 80:3850-3854.

Cremer H, Chazal G, Lledo PM, Rougon G, Montaron MF, Mayo W, Le Moal M, Abrous DN (2000) PSA-NCAM: an important regulator of hippocampal plasticity. Int J Dev Neurosci 18:213-220.

Davies SJ, Fitch MT, Memberg SP, Hall AK, Raisman G, Silver J (1997) Regeneration of adult axons in white matter tracts of the central nervous system. Nature 390:680-683.

Davies SJ, Goucher DR, Doller C, Silver J (1999) Robust regeneration of adult sensory axons in degenerating white matter of the adult rat spinal cord. J Neurosci 19:5810-5822.

Doucette R (1995) Olfactory ensheathing cells: potential for glial cell transplantation into areas of CNS injury. Histol Histopathol 10:502-507.

Dow KE, Ethell DW, Steeves JD, Riopelle RJ (1994) Molecular correlates of spinal cord repair in the embryonic chick: heparan sulfate and chondroitin sulfate proteoglycans. Exp Neurol 128:223-228.

Eckenhoff MF, Rakic P (1988) Nature and fate of proliferative cells in the hippocampal dentate gyrus during the life span of the rhesus monkey. J Neurosci 8:2729-2747.

Eddleston M, Mucke L (1993) Molecular profile of reactive astrocytesimplications for their role in neurologic disease. Neuroscience 54:15-36.

Edgar D, Timpl R, Thoenen H (1984) The heparin-binding domain of laminin is responsible for its effects on neurite outgrowth and neuronal survival. EMBO J 3:1463-1468.

Engler-Blum G, Meier M, Frank J, Miller GA (1993) Reduction of background problems in nonradioactive Northern and Southern blot analyses enables higher sensitivity than ${ }^{32} \mathrm{P}$-based hybridization. Anal Biochem 210:235-244

Engvall E, Davis GE, Dickerson K, Ruoslahti E, Varon S, Manthorpe M (1986) Mapping of domains in human laminin using monoclonal antibodies: localization of the neurite-promoting site. J Cell Biol 103:2457-2465.

Eriksson PS, Perfilieva E, Bjork-Eriksson T, Alborn AM, Nordborg C, 
Peterson DA, Gage FH (1998) Neurogenesis in the adult human hippocampus. Nat Med 4:1313-1317.

Ferguson TA, Muir D (2000) MMP-2 and MMP-9 increase the neuritepromoting potential of Schwann cell basal laminae and are upregulated in degenerated nerve. Mol Cell Neurosci 16:157-167.

Fischer D, Heiduschka P, Thanos S (2001) Lens-injury-stimulated axonal regeneration throughout the optic pathway of adult rats. Exp Neurol 172:257-272.

Fitch MT, Doller C, Combs CK, Landreth GE, Silver J (1999) Cellular and molecular mechanisms of glial scarring and progressive cavitation: in vivo and in vitro analysis of inflammation-induced secondary injury after CNS trauma. J Neurosci 19:8182-8198.

Fouad K, Dietz V, Schwab ME (2001) Improving axonal growth and functional recovery after experimental spinal cord injury by neutralizing myelin-associated inhibitors. Brain Res Brain Res Rev 36:204-212.

Fry EJ, Saunders NR (2000) Spinal repair in immature animals: a novel approach using the South American opossum Monodelphis domestica. Clin Exp Pharmacol Physiol 27:542-547.

Gaarskjaer FB (1986) The organization and development of the hippocampal mossy fiber system. Brain Res Brain Res Rev 11:355-357.

Gage FH, Coates PW, Palmer TD, Kuhn HG, Fisher LJ, Suhonen JO, Peterson DA, Suhr ST, Ray J (1995) Survival and differentiation of adult neuronal progenitor cells transplanted to the adult brain. Proc Natl Acad Sci USA 92:11879-11883.

Garcia-Abreu J, Cavalcante LA, Neto VM (1995) Differential patterns of laminin expression in lateral and medial midbrain glia. NeuroReport 6:761-764.

Giger RJ, Pasterkamp RJ, Heijnen S, Holtmaat AJ, Verhaagen J (1998) Anatomical distribution of the chemorepellent semaphorin III/ collapsin-1 in the adult rat and human brain: predominant expression in structures of the olfactory-hippocampal pathway and the motor system. J Neurosci Res 52:27-42.

Gonzales RB, DeLeon Galvan CJ, Rangel YM, Claiborne BJ (2001) Distribution of thorny excrescences on CA3 pyramidal neurons in the rat hippocampus. J Comp Neurol 430:357-368.

Gordon-Weeks PR, Giffin N, Weekes CS, Barben C (1989) Transient expression of laminin immunoreactivity in the developing rat hippocampus. J Neurocytol 18:451-463.

Grimpe B, Probst JC, Hager G (1999) Suppression of nidogen-1 translation by antisense targeting affects the adhesive properties of cultured astrocytes. Glia 28:138-149.

Groves AK, Entwistle A, Jat PS, Noble M (1993) The characterization of astrocyte cell lines that display properties of glial scar tissue. Dev Biol 159:87-104

Gundersen RW (1987) Response of sensory neurites and growth cones to patterned substrata of laminin and fibronectin in vitro. Dev Biol 121:423-431.

Haas CA, Rauch U, Thon N, Meten T, Deller T (1999) Entorhinal cortex lesion in adult rats induces the expression of the neuronal chondroitin sulfate proteoglycan neurocan in reactive astrocytes. J Neurosci 19:9953-9963.

Hagg T, Muir D, Engvall E, Varon S, Manthorpe M (1989) Laminin-like antigen in rat CNS neurons: distribution and changes upon brain injury and nerve growth factor treatment. Neuron 3:721-732.

Hagg T, Portera-Cailliau C, Jucker M, Engvall E (1997) Laminins of the adult mammalian CNS: laminin- $\alpha 2$ (merosin M-) chain immunoreactivity is associated with neuronal processes. Brain Res 764:17-27.

Halfter W (1996) The behavior of optic axons on substrate gradients of retinal basal lamina proteins and merosin. J Neurosci 16:4389-4401.

Harrigan MR, Kunkeel DD, Nguyen LB, Malouf AT (1995) Betaamyloid is neurotoxic in hippocampal slice cultures. Neurobiol Aging 16:779-789.

Harris KM, Kater SB (1994) Dendritic spines: cellular specializations imparting both stability and flexibility to synaptic function. Annu Rev Neurosci 17:341-371

Hunter DD, Shah V, Merlie JP, Sanes JR (1989) A laminin-like adhesive protein concentrated in the synaptic cleft of the neuromuscular junction. Nature 338:229-234.

Isacson O, Deacon TW, Pakzaban P, Galpern WR, Dinsmore J, Burns LH (1995) Transplanted xenogeneic neural cells in neurodegenerative disease models exhibit remarkable axonal target specificity and distinct growth patterns of glial and axonal fibres. Nat Med 1:1189-1194.

Ivins JK, Colognato H, Kreidberg JA, Yurchenco PD, Lander AD (1998) Neuronal receptors mediating responses to antibody-activated laminin-1. J Neurosci 18:9703-9715.

Jontes JD, Smith SJ (2000) Filopodia, spines, and the generation of synaptic diversity. Neuron 27:11-14.

Joosten EA, Dijkstra S, Brook GA, Veldman H, Bar PR (2000) Collagen IV deposits do not prevent regrowing axons from penetrating the lesion site in spinal cord injury. J Neurosci Res 62:686-691.

Jucker M, Kleinman HK, Hoehmann C, Ordy JM, Ingram DK (1991) Distinct immunoreactivity to $110 \mathrm{kDa}$ laminin-binding protein in adult and lesioned rat forebrain. Brain Res 555:305-312.

Kalil K, Reh T (1979) Regrowth of severed axons in the neonatal central nervous system: establishment of normal connections. Science 205:1158-1161.

Kaplan MS, Hinds JW (1977) Neurogenesis in adult rat: electron microscopic analysis of light radioautographs. Science 197:1092-1094.

Kennedy TE, Tessier-Lavigne M (1995) Guidance and induction of branch formation in developing axons by target-derived diffusible factors. Curr Opin Neurobiol 5:83-90.

Koch M, Olson PF, Albus A, Jin W, Hunter DD, Brunken WJ, Burgeson RE, Champliaud MF (1999) Characterization and expression of the laminin $\gamma 3$ chain: a novel, non-basement membrane-associated, laminin chain. J Cell Biol 145:605-618.

Korkotian E, Segal M (2001) Regulation of dendritic spine motility in cultured hippocampal neurons. J Neurosci 21:6115-6124.

Kuhn HG, Dickinson-Anson H, Gage FH (1996) Neurogenesis in the dentate gyrus of the adult rat: age-related decrease of neuronal progenitor proliferation. J Neurosci 16:2027-2033.

Kuhn TB, Schmidt MF, Kater SB (1995) Laminin and fibronectin guideposts signal sustained but opposite effects to passing growth cones. Neuron 14:275-285.

Kunkel DD, Nguyen LB, Harrigan MR, Schwartzkroin PA, Malouf AT (1994) Somatostatin-containing neurons in rat organotypic hippocampal slice cultures: light and electron microscopic immunocytochemistry. Hippocampus 4:157-166.

Kunkel-Bagden E, Dai HN, Bregman BS (1992) Recovery of function after spinal cord hemisection in newborn and adult rats: differential effects on reflex and locomotor function. Exp Neurol 116:40-51.

Laemmli UK (1970) Cleavage of structural proteins during the assembly of the head of bacteriophage T4. Nature 227:680-685.

Laurberg S, Zimmer J (1981) Lesion-induced sprouting of hippocampal mossy fiber collaterals to the fascia dentata in developing and adult rats. J Comp Neurol 200:433-459.

Lemons ML, Sandy JD, Anderson DK, Howland DR (2001) Intact aggrecan and fragments generated by both aggrecanase and metalloproteinase-like activities are present in the developing and adult rat spinal cord and their relative abundance is altered by injury. J Neurosci 21:4772-4781.

Leslie RA, Hunter AJ, Robertson HA (1999) Antisense technology in the central nervous system. New York: Oxford UP.

Letourneau PC, Madsen AM, Palm SL, Furcht LT (1988) Immunoreactivity for laminin in the developing ventral longitudinal pathway of the brain. Dev Biol 125:1-8.

Li D, Field PM, Yoshioka M, Raisman G (1994) Axons regenerate with correct specificity in horizontal slice culture of the postnatal rat entorhino-hippocampal system. Eur J Neurosci 6:1026-1037.

Li Y, Field PM, Raisman G (1999) Death of oligodendrocytes and microglial phagocytosis of myelin precede immigration of Schwann cells into the spinal cord. J Neurocytol 28:417-427.

Libby RT, Xu Y, Gibbons EP, Hunter DD, Brunken WJ (1997) Identification and localization of laminin chains in human retina. Invest Ophthalmol Vis Sci 38:S30.

Libby RT, Lavallee CR, Balkema GW, Brunken WJ, Hunter DD (1999) Disruption of laminin $\beta 2$ chain production causes alterations in morphology and function in the CNS. J Neurosci 19:9399-9411.

Liesi P (1990) Extracellular matrix and neuronal movement. Experientia 46:900-907.

Liesi P, Risteli L (1989) Glial cells of mammalian brain produce a variant form of laminin. Exp Neurol 105:86-92.

Liesi P, Silver J (1988) Is astrocyte laminin involved in axon guidance in the mammalian CNS? Dev Biol 130:774-785.

Liesi P, Seppala I, Trenkne E (1992) Neuronal migration in cerebellar microcultures is inhibited by antibodies against a neurite outgrowth domain of laminin. J Neurosci Res 33:170-176.

Luckenbill-Edds L (1997) Laminin and the mechanism of neuronal outgrowth. Brain Res Brain Res Rev 23:1-27.

Magavi SS, Leavitt BR, Macklis JD (2000) Induction of neurogenesis in the neocortex of adult mice. Nature 405:951-955.

Manitt C, Colicos MA, Thompson KM, Rousselle E, Peterson AC, Kennedy TE (2001) Widespread expression of netrin-1 by neurons and oligodendrocytes in the adult mammalian spinal cord. J Neurosci 21:3911-3922

Manthorpe M, Engvall E, Ruoslahti E, Longo FM, Davis GE, Varon S (1983) Laminin promotes neuritic regeneration from cultured peripheral and central neurons. J Cell Biol 97:1882-1890.

Matsuzawa M, Weight FF, Potember RS, Liesi P (1996) Directional neurite outgrowth and axonal differentiation of embryonic hippocampal neurons are promoted by a neurite outgrowth domain of the B2 chain of laminin. Int J Dev Neurosci 14:283-295.

McKeon RJ, Hoke A, Silver J (1995) Injury-induced proteoglycans inhibit the potential for laminin-mediated axon growth on astrocytic scars. Exp Neurol 136:32-43.

McLoon SC, McLoon LK, Palm SL, Furcht LT (1988) Transient expression of laminin in the optic nerve of the developing rat. J Neurosci 8:1981-1990.

McWilliams JR, Lynch G (1983) Rate of synaptic replacement in dener- 
vated rat hippocampus declines precipitously from the juvenile period to adulthood. Science 221:572-574.

Miller PD, Chung WW, Lagenaur CR, DeKosky ST (1993) Regional distribution of neural cell adhesion molecule (N-CAM) and L1 in human and rodent hippocampus. J Comp Neurol 327:341-349.

Mitchell KJ, Doyle JL, Serafini T, Kennedy TE, Tessier-Lavigne M, Goodman CS, Dickson BJ (1996) Genetic analysis of netrin genes in Drosophila: netrins guide CNS commissural axons and peripheral motor axons. Neuron 17:203-215.

Mizuhashi S, Nishiyama N, Matsuki N, Ikegaya Y (2001) Cyclic nucleotide-mediated regulation of hippocampal mossy fiber development: a target-specific guidance. J Neurosci 21:6181-6194.

Nakagami Y, Abe K, Nishiyama N, Matsuki N (2000) Laminin degradation by plasmin regulates long-term potentiation. J Neurosci 20:2003-2010.

Nguyen LB, Ricciardi TN, Malouf AT (1996) Reinnervation of stratum lucidum by hippocampal mossy fibers is developmentally regulated. Brain Res Dev Brain Res 95:184-193.

Niederost BP, Zimmermann DR, Schwab ME, Bandtlow CE (1999) Bovine CNS myelin contains neurite growth-inhibitory activity associated with chondroitin sulfate proteoglycans. J Neurosci 19:8979-8989.

Nieto-Sampedro M, Bovolenta P (1990) Growth factors and growth factor receptors in the hippocampus. Role in plasticity and response to injury. Prog Brain Res 83:341-355.

Nudel U, Zakut R, Shani M, Neuman S, Levy Z, Yaffa D (1983) The nucleotide sequence of the rat cytoplasmic $\beta$-actin gene. Nucleic Acids Res 11:1759-1771.

Obremski VJ, Bunge MB (1995) Addition of purified basal lamina molecules enables Schwann cell ensheathment of sympathetic neurites in culture. Dev Biol 168:124-137.

O'Keefe J, Nadel L (1978) The hippocampus as a cognitive map, pp 102-140. New York: Oxford UP.

Oleszewski M, Beer S, Katich S, Geiger C, Zeller Y, Rauch U, Altevogt $\mathrm{P}$ (1999) Integrin and neurocan binding to L1 involves distinct Ig domains. J Biol Chem 274:24602-24610.

Olsen BR (1999) Life without perlecan has its problems. J Cell Biol 147:909-911.

Pasterkamp RJ, Giger RJ, Ruitenberg MJ, Holtmaat AJGD, De Wit J, De Winter F, Verhaagen J (1999) Expression of the gene encoding the chemorepellent semaphorin III is induced in the fibroblast component of neural scar tissue formed following injuries of adult, but not neonatal, CNS. Mol Cell Neurosci 13:143-166.

Patton BL, Miner JH, Chiu AY, Sanes JR (1997) Distribution and function of laminins in the neuromuscular system of developing, adult, and mutant mice. J Cell Biol 139:1507-1521.

Payne HR, Lemmon V (1993) Glial cells of the O-2A lineage bind preferentially to $\mathrm{N}$-cadherin and develop distinct morphologies. Dev Biol 159:595-607.

Peterson DA (2002) Stem cells in brain plasticity and repair [portion of figure on cover]. Curr Opin Pharmacol 2:34-42.

Pindzola RR, Doller C, Silver J (1993) Putative inhibition extracellular matrix molecules at the dorsal root entry zone of the spinal cord during development and after root and sciatic nerve lesion. Dev Biol 156:34-48.

Powell SK, Rao J, Roque E, Nomizu M, Kuratomi Y, Yamada Y, Kleinman HK (2000) Neural cells respond to multiple novel sites on laminin-1. J Neurosci Res 61:302-312.

Prange O, Murphy TH (2001) Modular transport of postsynaptic density-95 clusters and association with stable spine precursors during early development of cortical neurons. J Neurosci 21:9325-9333.

Probst JC, Skutella T (1996) Elevated messenger RNA levels after antisense oligodeoxynucleotide treatment in vitro and in vivo. Biochem Biophys Res Commun 225:861-868.

Raisman G (1985) Specialized neuroglial arrangement may explain the capacity of vomeronasal axons to reinnervate central neurons. Neuroscience 14:237-254.

Ramon-Cueto A, Avila J (1998) Olfactory ensheathing glia: properties and function. Brain Res Bull 46:175-187.

Renaudin A, Lehmann M, Girault JA, McKerracher L (1999) Organization of point contacts in neuronal growth cones. J Neurosci Res 55:458-471.

Rudge JS, Silver J (1990) Inhibition of neurite outgrowth on astroglial scars in vitro. J Neurosci 10:3594-3603.

Sambrook J, Fritsch EF, Maniatis T (1989) Molecular cloning: a laboratory manual. Cold Spring Harbor, NY: Cold Spring Harbor Laboratory.

Santoro SW, Joyce GF (1997) A general purpose RNA-cleaving DNA enzyme. Proc Natl Acad Sci USA 94:4262-4266.

Sasaki M, Yamada Y (1987) The laminin B2 chain has a multidomain structure homologous to the B1 chain. J Biol Chem 262:17111-17117.

Scharff C, Kirn JR, Grossman M, Macklis JD, Nottebohm F (2000) Targeted neuronal death affects neuronal replacement and vocal behavior in adult songbirds. Neuron 25:481-492.

Schmidt CE, Dai J, Lauffenburger DA, Sheetz MP, Horwitz AF (1995) Integrin-cytoskeletal interactions in neuronal growth cones. J Neurosci $15: 3400-3407$
Seil FJ (1998) The extracellular matrix molecule, laminin, induces Purkinje cell dendritic spine proliferation in granule cell-depleted cerebellar cultures. Brain Res 795:112-120.

Seki T, Arai Y (1991) The persistent expression of a highly polysialylated NCAM in the dentate gyrus of the adult rat. Neurosci Res 12:503-513.

Seki T, Rutishauser U (1998) Removal of polysialic acid-neural cell adhesion molecule induces aberrant mossy fiber innervation and ectopic synaptogenesis in the hippocampus. J Neurosci 18:3757-3766.

Seri B, Garcia-Verdugo JM, McEwen BS, Alvarez-Buylla A (2001) Astrocytes give rise to new neurons in the adult mammalian hippocampus. J Neurosci 21:7153-7160.

Smith GM, Miller RH, Silver J (1986) Changing role of forebrain astrocytes during development, regenerative failure, and induced regeneration upon transplantation. J Comp Neurol 251:23-43.

Smith GM, Rutishauser U, Silver J, Miller RH (1990) Maturation of astrocytes in vitro alters the extent and molecular basis of neurite outgrowth. Dev Biol 138:377-390.

Smyth N, Vatansever HS, Murray P, Meyer M, Frie C, Paulson M, Edgar D (1999) Absence of basement membrane after targeting the LAMC1 gene results in embryonic lethality due to failure of endoderm differentiation. J Cell Biol 144:151-160.

Steup A, Lohrum M, Hamscho N, Savaskan NE, Nimmemann O, Nitsch R, Fujisawa H, Pöschel AW, Skutella T (2000) Sema3C and netrin-1 differentially affect axon growth in the hippocampal formation. Mol Cell Neurosci 15:141-155.

Steward O (1976) Reinnervation of dentate gyrus by homologous afferents following entorhinal cortical lesions in adult rats. Science 194:426-428.

Stichel CC, Muller HW (1994) Relationship between injury-induced astrogliosis, laminin expression, and axonal sprouting in the adult rat brain. J Neurocytol 23:615-630.

Stoppini L, Buchs PA, Muller D (1991) A simple method for organotypic cultures of nervous tissue. J Neurosci Methods 37:173-182.

Tang S, Qiu J, Nikulina E, Filbin MT (2001) Soluble myelin-associated glycoprotein released from damaged white matter inhibits axonal regeneration. Mol Cell Neurosci 18:259-269.

Timpl R, Rodde H, Robey PG, Rennard SI, Foidart J-M, Martin GR (1979) Laminin - a glycoprotein from basement membrane. J Biol Chem 254:9933-9937.

Tomaselli KJ, Doherty P, Emmett CJ, Damsky CH, Walsh FS, Reichardt LF (1993) Expression of $\gamma 1$ integrin in sensory neurons of the dorsa root ganglion and their functions in neurite outgrowth on two laminin isoforms. J Neurosci 13:4880-4888.

Tsui HCT, Lankford KL, Klein WL (1985) Differentiation of neuronal growth cones: specialization of filopodial tips for adhesive interactions. Proc Natl Acad Sci USA 2:8256-8260.

Vanden Heuvel GB, Leardkamolkarn V, St. John PL, Abrahamson DR (1996) Carboxy terminal sequence and synthesis of rat kidney laminin $\gamma 1$ chain. Kidney Int 49:752-760.

van Praag H, Christie BR, Palmer TD, Gage FH (2000) Characterization of retrovirally labeled newborn granule cells in the adult mouse dentate gyrus. 30th Annual Meeting Society for Neuroscience, New Orleans, LA.

Walsh FS, Doherty P (1997) Neural cell adhesion molecules of the immunoglobulin superfamily: role in axon growth and guidance. Annu Rev Cell Dev Biol 13:425-456.

Willbold E, Rothermel A, Tomlinson S, Layer PG (2000) Mueller glia cells reorganize reaggregating chicken retinal cells into correctly laminated in vitro retinae. Glia 29:45-57.

Wilson MT, Snow DM (2000) Chondroitin sulfate proteoglycan expression pattern in hippocampal development: potential regulation of axon tract formation. J Comp Neurol 424:532-546.

Wong EV, Kenwrick S, Willems P, Lemmon V (1995) Mutations in the cell adhesion molecule L1 cause mental retardation. Trends Neurosci $18: 168-172$

Woolhead CL, Zhang Y, Liebermann AR, Schachner M, Emson PC, Anderson PN (1998) Differential effects of autologous peripheral nerve grafts to the corpus striatum of adult rats on the regeneration of axons of striatal and nigral neurons and on the expression of GAP-43 and the cell adhesion molecules N-CAM and L1. J Comp Neurol 391:259-273

Wu GY, Zou DJ, Rajan I, Cline H (1999) Dendritic dynamics in vivo change during neuronal maturation. J Neurosci 19:4472-4483.

Wujek JR, Haleem-Smith H, Yamada Y, Lipsky R, Lan YT, Freese E (1990) Evidence that the B2 chain of laminin is responsible for the neurite outgrowth-promoting activity of astrocyte extracellular matrix. Brain Res Dev Brain Res 55:237-247.

Zhou FC (1990) Four patterns of laminin-immunoreactive structure in developing rat brain. Brain Res Dev Brain Res 55:191-201.

Zimmer J, Gähwiler BH (1987) Growth of hippocampal mossy fibers: a lesion and coculture study of organotypic slice cultures. J Comp Neurol 264:1-13. 